\title{
Critical role for cathepsin B in mediating caspase-1- dependent interleukin-18 maturation and caspase-1- independent necrosis triggered by the microbial toxin nigericin
}

\author{
H Hentze ${ }^{1,2}$ XY Lin ${ }^{1,2,3}$, MSK Choi ${ }^{1}$ and AG Porter*,1 \\ ${ }^{1}$ Institute of Molecular and Cell Biology, Singapore, Republic of Singapore \\ * Corresponding author: AG Porter, Institute of Molecular and Cell Biology, 30 \\ Medical Drive, Singapore 117609, Republic of Singapore. Tel: +65-6874-3761; \\ Fax: +65-6779-1117; E-mail: mcbagp @imcb.nus.edu.sg \\ 2 Both authors contributed equally to this work \\ ${ }^{3}$ Current address: Department of Biochemistry, Molecular Biology and Cell \\ Biology, Northwestern University, Evanston, IL 60208, USA
}

Received 16.10.02; revised 3.3.03; accepted 24.3.03

Edited by S. Nagata

\begin{abstract}
The potassium ionophore nigericin induces cell death and promotes the maturation and release of IL-1 $\beta$ in lipopolysaccharide (LPS)-primed monocytes and macrophages, the latter depending on caspase-1 activation by an unknown mechanism. Here, we investigate the pathway that triggers cell death and activates caspase-1. We show that without LPS priming, nigericin alone triggered caspase-1 activation and IL18 generation in THP-1 monocytic cells. Simultaneously, nigericin induced caspase-1-independent necrotic cell death, which was blocked by the cathepsin B inhibitor CA-074-Me and other cathepsin inhibitors. Cathepsin B activation after nigericin treatment was determined biochemically and corroborated by rapid lysosomal leakage and translocation of cathepsin B to the cytoplasm. IL-18 maturation was prevented by both caspase-1 and cathepsin B inhibitors in THP-1 cells, primary mouse macrophages and human blood monocytes. Moreover, IL-18 generation was reduced in THP-1 cells stably transformed either with cystatin $A$ (an endogenous cathepsin inhibitor) or antisense cathepsin B cDNA. Collectively, our study establishes a critical role for cathepsin $B$ in nigericin-induced caspase-1-dependent IL-18 maturation and caspase-1-independent necrosis.

Cell Death and Differentiation (2003) 10, 956-968. doi:10.1038/ sj.cdd. 4401264
\end{abstract}

Keywords: monocyte; lipopolysaccharide; nigericin; caspase; interleukin; necrosis

Abbreviations: pro-IL-1 $\beta$, prointerleukin-1 $\beta$; pro-IL-18, prointerleukin-18; LPS, lipopolysaccharide; ICE, IL-1 $\beta$-converting enzyme; TLR, Toll-like receptor; ALLN, Ac-Leu-Leu-Asn aldehyde; zYVAD-cmk, z-Tyr-Val-Ala-Asp-chloromethylketone; zDEVD-fmk, z-Asp(OMe)-Glu(OMe)-Val-DL-Asp(OMe) fluoro- methylketone; zVAD-fmk, z-Val-Ala-DL-Asp-fluoromethylketone; CA-074, L-trans-epoxysuccinyl-Ile-Pro-OH propylamide; zVF, zVal-Phe-aldehyde; zLLL, z-Leu-Leu-Leu-aldehyde; CA-074-Me, L-trans-epoxysuccinyl-Ile-Pro-OMe propylamide; zDEVD-afc, z-Asp-Glu-Val-DL-Asp-7-amino-4-trifluoromethylcoumarin; zYVAD-afc, $\quad \mathrm{N}$-acetyl-Tyr-Val-Ala-Asp-7-amino-4-trifluoromethylcoumarin; zRR-amc, z-Arg-Arg-7-amino-4-methylcoumarin; zFR-amc, z-Phe-Arg-7-amino-4-methylcoumarin; CHAPS, 3([-3-cholamidopropyl) dimethylammonio]-1-propanesulfonic acid; PMA, phorbol-myristate acetate; MNC, mononuclear cells

\section{Introduction}

$\mathrm{IL}-1 \beta$ and IL-18, formerly called interferon- $\gamma$-inducing factor, are two proinflammatory cytokines that share many similarities. Both proteins are produced by monocytes and macrophages activated by inflammatory stimuli such as lipopolysaccharide (LPS). They are first synthesized in the cytoplasm as biologically inactive precursors without a typical signal peptide, followed by proteolytic cleavage by the IL-1 $\beta$ converting enzyme (ICE, caspase-1). ${ }^{1-3}$ The production of mature IL-1 $\beta$ and IL-18 is under tight control. Firstly, on the level of gene expression, the basal level of pro-IL-1 $\beta$ is usually undetectable in cells and is rapidly induced by LPS, whereas pro-IL-18 is constitutively synthesized. ${ }^{4,5}$ The second layer of control is at the level of caspase-1, a protease essential for the maturation of both cytokines. The physiological regulation of caspase-1 activation, however, is still poorly defined. ${ }^{6,7}$ Thirdly, it appears that the maturation and release of the mature cytokines occurs concurrently under normal conditions, but the release itself is independent of caspase- 1 activity and employs a nonclassical secretion pathway. ${ }^{8,9}$

Under in vitro conditions, monocytes and macrophages produce massive amounts of pro-IL- $1 \beta$ in the cytoplasm upon LPS stimulation, but only very little mature $\mathrm{IL}-1 \beta$ is released in the culture medium. Several substances have been described that boost IL-1 $\beta$ production when given in combination with LPS, i.e. ATP, several bacterial toxins and the Streptomyces toxin nigericin. ${ }^{10-13}$ Nigericin is a potassium ionophore and thus induces potassium efflux and intracellular acidification, and potassium depletion has been shown to be crucial for enhancing IL-1 $\beta$ processing. ${ }^{12,13}$ Recent studies suggested that both ATP and nigericin induce caspase- 1 activation in LPS-stimulated cells, ${ }^{14,15}$ and ionophore toxins of microbial origin have been shown to induce cell death in certain cell types. ${ }^{16-18}$

However, the primary mechanisms by which the abovementioned secondary stimuli facilitate caspase-1 activation or induce cell death are entirely unknown. Notably, the LPStriggered pathway that connects the activation of Toll-like 
receptors (TLRs) to caspase-1 activation also remains unclear. It is now evident that the proinflammatory proteases caspase-11 (mouse) and caspase-5 (human) are to be placed upstream of caspase- 1 in certain experimental systems, ${ }^{5,19}$ and it was reported that caspase- 1 can be activated by forming a complex termed 'inflammasome' with caspase-5, Pycard and NALP $-1 .{ }^{20}$ In a different approach, it was revealed that the lysosomal protease cathepsin $B$ is capable of activating caspase- 11 under cell-free conditions. ${ }^{21,22} \mathrm{~A}$ cell culture model that recapitulates the caspase-activating potential of cathepsin $\mathrm{B}$, a protease that has also been implicated in death receptor-mediated apoptosis recently, ${ }^{23-26}$ has not been described.

Here, we report the novel finding that in the absence of LPS priming, nigericin alone readily activates caspase- 1 and initiates the processing and release of mature IL-18 from THP-1 monocytic cells. Moreover, we observed that nigericin alone induces cathepsin B activity and release from the lysosomal compartment, and rapid caspase-1-independent necrotic cell death ensues. Using different approaches, we found that blocking cathepsin B activity blunts both IL-18 processing and necrosis. Thus, we describe a physiologically relevant paradigm where upon treatment with the microbial toxin nigericin, cathepsin B is placed upstream of caspase-1 activation and IL-18 processing and mediates concomitant necrotic cell death in monocytic cells.

\section{Results}

\section{Nigericin alone induces caspase-1 activation and IL-18 generation in THP-1 cells}

In THP-1 monocytic cells, LPS triggers the protein synthesis of prointerleukin-1 $\beta$ (pro-IL-1 $\beta$ ). ${ }^{5}$ This is followed by the release of mature $\mathrm{IL}-1 \beta$ in the cell culture supernatant, which was greatly enhanced by cotreatment with nigericin (Figure 1a, right side). Since nigericin does not initiate synthesis of pro-IL-1 $\beta$ (data not shown), it is expected that no production of mature IL-1 $\beta$ was seen in the absence of LPS (Figure 1a, left side). In contrast, prointerleukin-18 (pro-IL-18) is constitutively present in monocytes (Puren et al. ${ }^{4}$ and data not shown). Here, the LPS-inducible amount of mature IL-18 in the supernatant as detected with a cleaved IL-18-specific ELISA $^{27,28}$ was again increased by nigericin treatment (Figure $1 \mathrm{~b}$, right side), but additionally, a time-dependent release of

Figure 1 Nigericin alone activates caspase- 1 and stimulates the production of mature IL-18. THP-1 cells were either untreated (untr.), stimulated with $1 \mu \mathrm{g} / \mathrm{ml}$ LPS for $3 \mathrm{~h}$ alone (LPS), or additionally treated with $20 \mu \mathrm{M}$ nigericin for $30 \mathrm{~min}$ (LPS+nig.); additionally, cells were treated with $20 \mu \mathrm{M}$ nigericin alone for the indicated times. Medium was collected and assayed for IL-1 $\beta$ (a) and IL-18 (b) using a human IL-1 $\beta$-specific ELISA and a human IL-18-specific ELISA, respectively. Additionally in (b), cells were preincubated with $100 \mu \mathrm{M}$ zYVAD-cmk $1 \mathrm{~h}$ before addition of $20 \mu \mathrm{M}$ nigericin for $2 \mathrm{~h}$. (c) THP-1 cells were either untreated or treated with $20 \mu \mathrm{M}$ nigericin for $2 \mathrm{~h}$ in the presence or absence of $100 \mu \mathrm{M} z$ YVAD-cmk. The medium was collected, proteins in the medium were concentrated as under 'Materials and Methods', and samples were analyzed by Western blotting using an anti-IL-18 antibody. Arrows indicate the precursor and mature forms of IL-18. (d) Cytosolic proteins were prepared as in (a) and analyzed by Western blotting using an anti-caspase-1 mouse monoclonal antibody. Arrows indicate the precursor form of caspase- 1 and the p35/p37 kDa intermediate forms of caspase-1 mature IL-18 with nigericin alone was observed (Figure 1b, left side). A caspase-1 inhibitor, z-Tyr-Val-Ala-Asp-chloromethylketone (zYVAD-cmk), blocked this release (Figure $1 \mathrm{~b}$, left side), confirming that nigericin-stimulated generation of IL-18 requires caspase- 1 activity. ${ }^{2}$ Western blotting of IL-18 recovered from the supernatant revealed that mature IL-18 protein $(\sim 18 \mathrm{kDa})$ could be detected only in medium derived
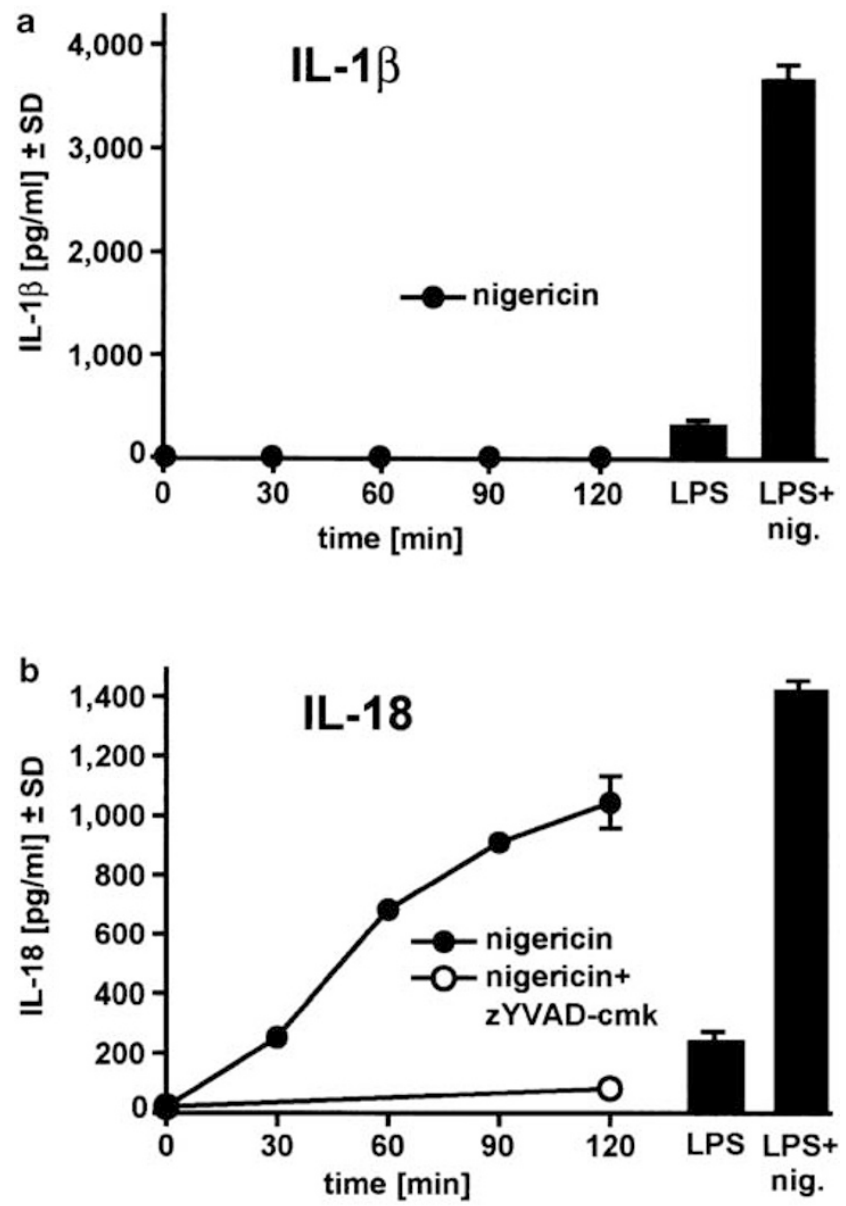

c

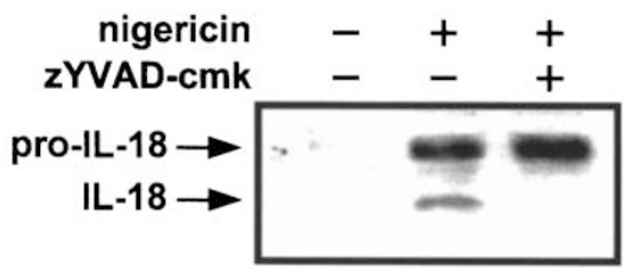

d LPS+ nigericin [min] untr. LPS nig. $\begin{array}{llll}30 & 60 & 90 & 120\end{array}$

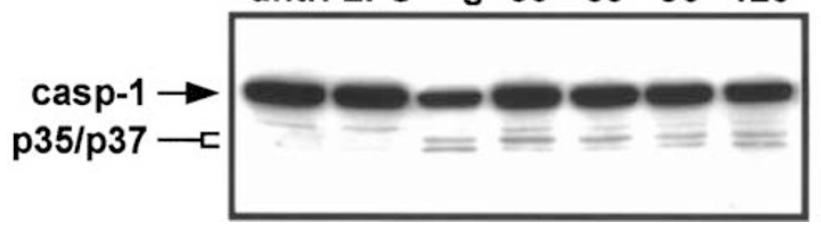


from nigericin-treated cells, but not from untreated or nigericin/zVYAD-cmk-treated cells (Figure 1c). The pro-IL18 protein $(\sim 24 \mathrm{kDa})$ band observed in nigericin/zVYADcmk-treated cell supernatants was because of nigericininduced necrosis not prevented by zVYAD-cmk (see below). We further examined caspase-1 status by Western blotting (Figure 1d). In LPS-primed THP-1 cells, nigericin caused a decrease of caspase-1 precursor and the appearance of p35/ p37 kDa bands of activated caspase-1 resulting from the cleavage between the $\mathrm{p} 20$ and $\mathrm{p} 10$ subunits. ${ }^{29}$ These bands were also observed from 30 min after nigericin treatment alone, demonstrating that nigericin also activates caspase-1 in the absence of LPS priming. These data indicate that nigericin alone can promote the maturation of $\mathrm{IL}-18$ in a caspase-1-dependent manner.

\section{Nigericin induces IL-18 in a LPS-independent manner in primary mouse macrophages}

In parallel, we checked the IL-18-processing potential of nigericin in primary mouse peritoneal macrophages isolated from both LPS-sensitive FVBN mice and from LPS-unresponsive $\mathrm{C} 3 \mathrm{H} / \mathrm{HeJ}$ mice. The latter mouse strain is LPSunresponsive due to a point mutation in the Toll-like receptor 4 (TLR-4). ${ }^{30}$ Treatment with LPS alone did not induce a significant release of IL-18 in macrophages of both mouse strains (Figure 2), unlike in THP-1 cells (Figure 1b). As expected, nigericin induced a vigorous release of mature

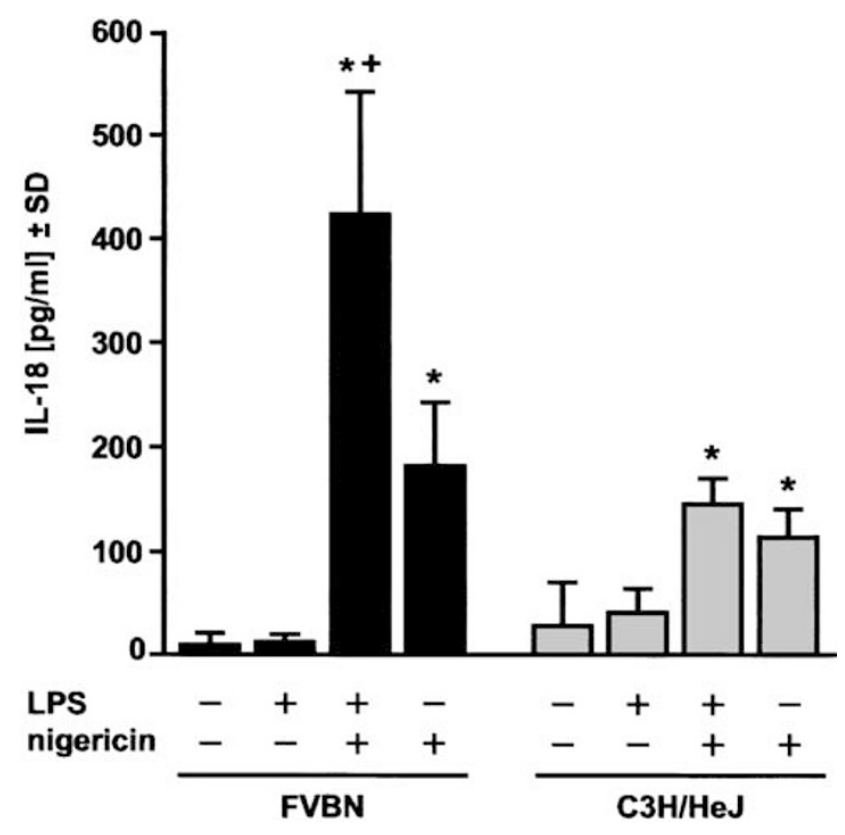

Figure 2 Nigericin stimulates the production of mature $\mathrm{L}-18$ in primary peritoneal macrophages. Peritoneal macrophages were prepared from FVBN or $\mathrm{C} 3 \mathrm{H} / \mathrm{HeJ}$ mice as described under 'Materials and Methods', and allowed to adhere overnight. After exchanging the medium, adherent peritoneal macrophages were either left untreated, stimulated with $1 \mu \mathrm{g} / \mathrm{ml}$ LPS alone for $3.5 \mathrm{~h}$, treated with $1 \mu \mathrm{g} / \mathrm{ml}$ LPS for $30 \mathrm{~min}$ followed by $20 \mu \mathrm{M}$ nigericin for $3 \mathrm{~h}$, or treated with $20 \mu \mathrm{M}$ nigericin alone for $3 \mathrm{~h}$ as indicated. Then, supernatants were assayed for mature murine IL-18 by ELISA (three combined experiments). Triplicate determinations and an ANOVA followed by the Tukey multiple comparison test was performed, including all experimental groups, *: versus con, + , versus nigericin, $P<0.01$ was considered significant
IL-18 in LPS-primed macrophages derived from FVBN mice; notably, significant although lower levels of released IL-18 were also detected when nigericin alone was used (Figure 2). In contrast, nigericin-treated macrophages prepared from $\mathrm{C} 3 \mathrm{H} / \mathrm{HeJ}$ mice released similar amounts of IL-18 regardless of LPS-priming (Figure 2). These results show that IL-18 maturation can be reiterated in mouse macrophages, and is due to nigericin alone and is not the result of contamination of nigericin with LPS.

\section{Nigericin causes cathepsin B-dependent necrosis in THP-1 cells}

It has been reported previously that nigericin induces cell death in LPS-primed monocytes or macrophages. ${ }^{11,17,31} \mathrm{We}$
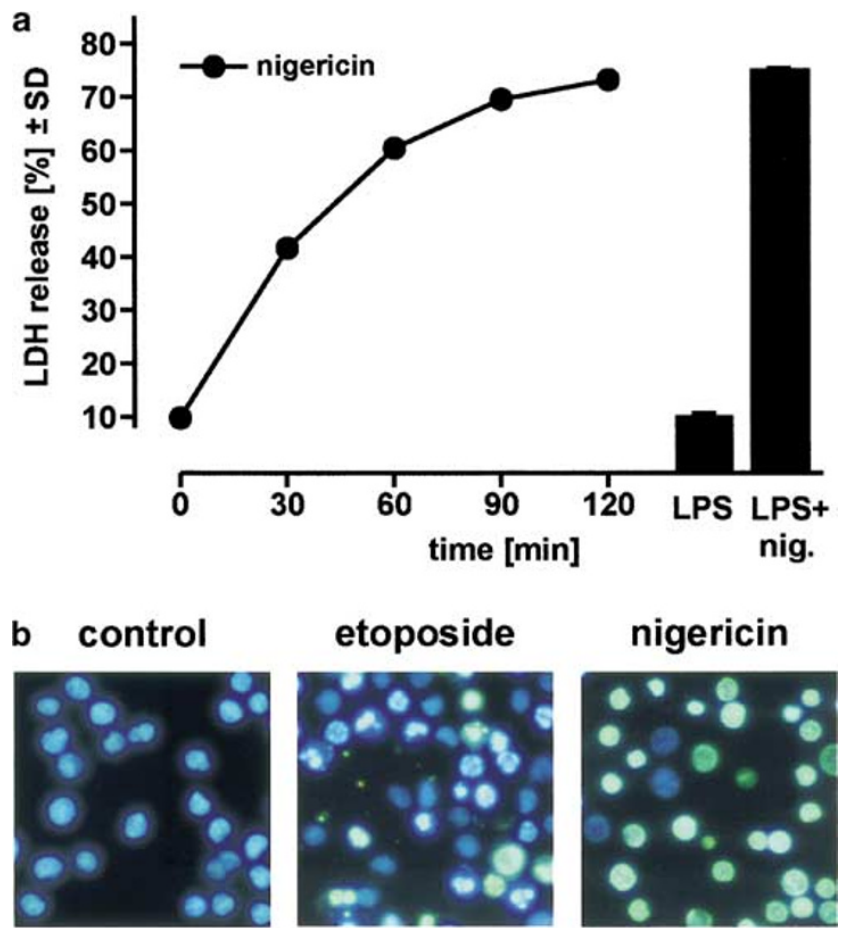

nigericin
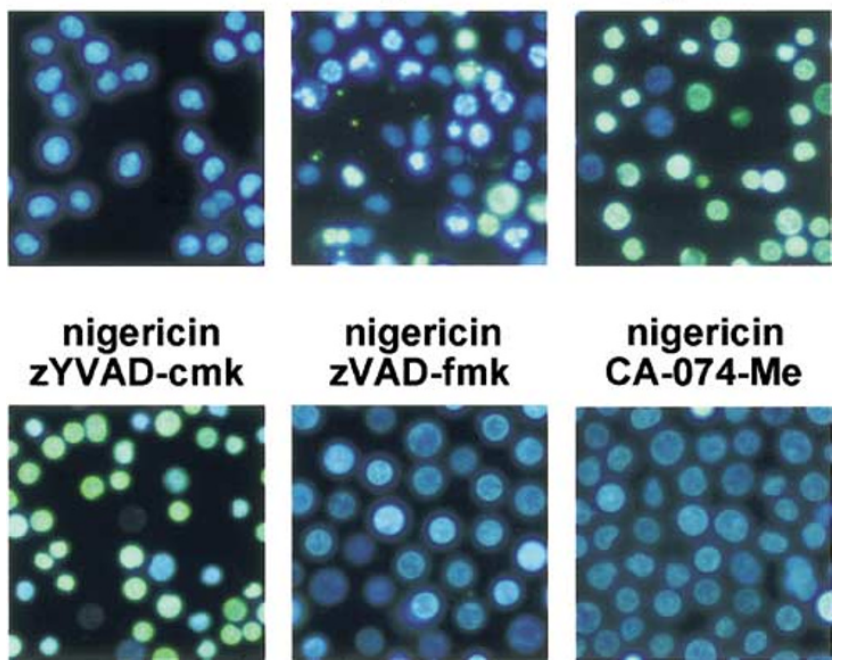

Figure 3 Nigericin induces necrosis in THP- 1 cells. (a) THP- 1 cells $\left(10^{6}\right.$ cells/ sample) were stimulated with $20 \mu \mathrm{M}$ nigericin for the indicated times, and cell death was determined by measurement of LDH release. Additionally, cells were pretreated with $1 \mu \mathrm{g} / \mathrm{ml}$ LPS for $3 \mathrm{~h}$ and then incubated either with medium alone or with $20 \mu \mathrm{M}$ nigericin for $30 \mathrm{~min}$ (black bars). (b) THP-1 cells were incubated with etoposide $(10 \mu \mathrm{M})$ or nigericin $(20 \mu \mathrm{M})$ as indicated, stained with $\mathrm{H}-33342$ plus SYTOX, and fluorescence images were taken (original magnification $\times 120$, etoposide: $4 \mathrm{~h}$, nigericin: $2 \mathrm{~h}$ ). Additionally, cells were pretreated for $1 \mathrm{~h}$ with the caspase inhibitors zYVAD-cmk and zVAD-fmk, or with the cathepsin B inhibitor $\mathrm{CA}-074-\mathrm{Me}$ for $1 \mathrm{~h}($ all $100 \mu \mathrm{M})$, and then treated with $20 \mu \mathrm{M}$ nigericin for $2 \mathrm{~h}$ 
also observed extensive cell death within $30 \mathrm{~min}$ in LPSprimed, nigericin-stimulated THP-1 cells (Figure 3a, right side), whereas nigericin alone was able to induce a similar extent of cell death in these cells over a period of $2 \mathrm{~h}$ (Figure $3 a$, left side).

The type of nigericin-induced cell death in LPS-primed cells is controversial, since both apoptosis and necrosis have been reported in the literature. ${ }^{17,31}$ In THP-1 cells, we found that cell death induced by nigericin alone displayed characteristics typical for necrosis (Figure 3b), accompanied by a rapid release of the cellular contents (Figure 3a). Furthermore, we did not observe any nuclear condensation or chromatin fragmentation (Figure $3 \mathrm{~b}$ ), and there was no activity of caspase-3-like proteases detected in cytosolic samples at any time point. Also, even high concentrations of the caspase3-like protease inhibitor z-Asp(OMe)-Glu(OMe)-Val-DL-As$\mathrm{p}(\mathrm{OMe})$ fluoromethylketone (zDEVD-fmk) consistently failed to rescue cells from nigericin-induced death (c.f. Figure 4a). Nigericin-induced necrosis in THP-1 cells is also unlikely to be a secondary event after apoptosis, since we were never able to capture any apoptotic cells by using short periods of nigericin treatment or low drug concentrations (data not shown). In contrast, etoposide-induced cell death in THP-1 cells ${ }^{32}$ clearly displayed typical features of apoptosis, as judged by condensed cell bodies and fragmented nuclei (Figure 3b, upper middle panel; the green cells represent cells at a late stage of apoptosis with damaged cell membranes, which become SYTOX-permeable).

Since caspase- 1 has been implicated in inflammation that is often associated with necrosis, ${ }^{33,34}$ we tested whether caspase-1 activity is required for nigericin-induced necrosis. Although preincubation of THP-1 cells with $100 \mu \mathrm{M}$ zYVAD$\mathrm{cmk}$ completely blocked the production of mature IL-18 by nigericin (Figure 1b,c), the same concentration of zYVADcmk failed to inhibit nigericin-induced necrosis, suggesting that cell death is caspase-1-independent (Figures $3 b$ and $4 a$ ). Interestingly, a broad-spectrum caspase inhibitor, z-Val-AlaDL-Asp-fluoromethylketone (zVAD-fmk), completely blocked nigericin-induced necrosis at $100 \mu \mathrm{M}$ (Figures $3 \mathrm{~b}$ and $4 \mathrm{a}$ ). These results are similar to a previous report in which different potassium depletion reagents were used to induce cell death in THP-1 cells. ${ }^{17}$

However, it has been reported that zVAD-fmk is not a specific caspase inhibitor, but rather is a potent cathepsin $B$ inhibitor when used at higher concentrations. ${ }^{35}$ Since zVADfmk was effective in blocking cell death in our experiments, we studied the effect of a panel of other protease inhibitors on

Figure 4 Nigericin-induced necrosis is cathepsin B-dependent. (a) THP-1 cells were preincubated for $1 \mathrm{~h}$ with the indicated protease inhibitors (ZYVAD-cmk, $100 \mu \mathrm{M}$; leupeptin, $20 \mu \mathrm{M}$; pepstatin A, preloading for $24 \mathrm{~h}$ with $100 \mu \mathrm{M}$; zDEVDcmk, $100 \mu \mathrm{M}$; ALLN, $200 \mu \mathrm{M}$; zVAD-fmk, $100 \mu \mathrm{M}$; CA-074-Me, $100 \mu \mathrm{M}$ ), and then treated with $20 \mu \mathrm{M}$ nigericin for $2 \mathrm{~h}$. Cell death was determined by measurement of LDH release. Untr., untreated. (b) THP-1 cells were preincubated for $1 \mathrm{~h}$ with serial dilutions of the inhibitors $\mathrm{ZVAD}$-fmk and $\mathrm{CA}$ 074-Me as indicated and then treated with $20 \mu \mathrm{M}$ nigericin for $2 \mathrm{~h}$, and cell death was determined by measurement of LDH release. (c) and (d): Long-term protection from nigericin-induced necrosis; undifferentiated (c) or differentiated adherent (diff.) THP1 cells (d) were incubated for $1 \mathrm{~h}$ with or without CA-074-Me $(\mathrm{CA})$, and the nigericin-triggered cell death was quantitated at the indicated time points. Values are given as means $\pm S D$ from triplicate determinations

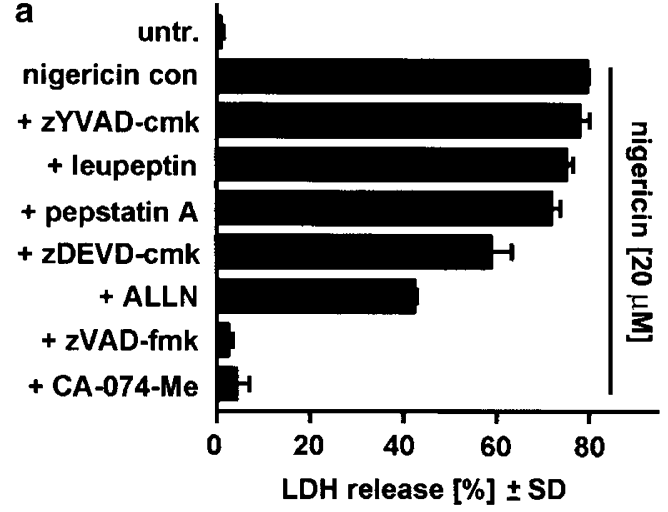

b

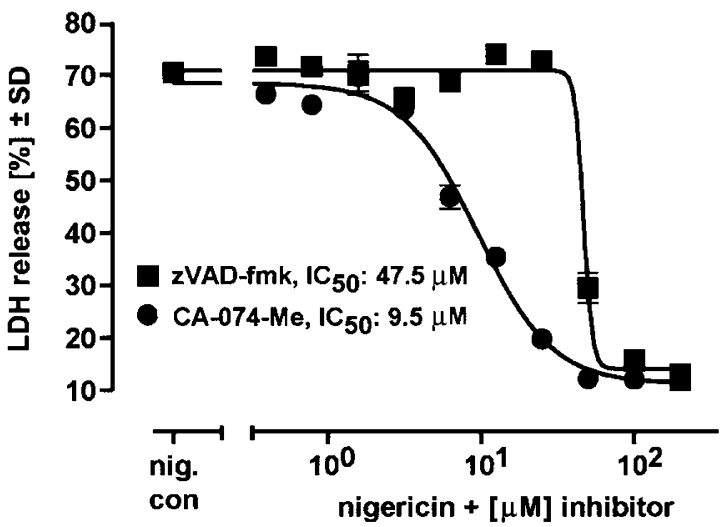

c

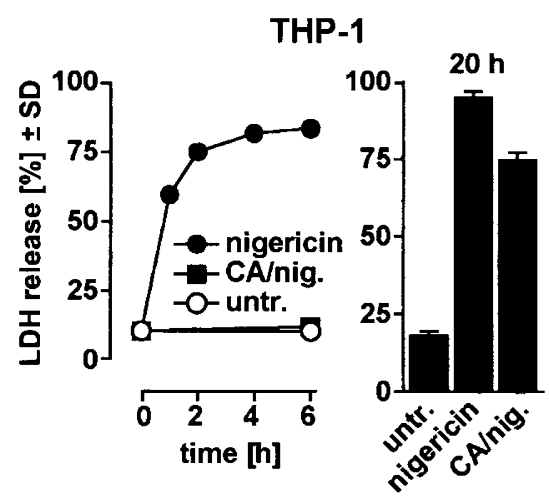

d

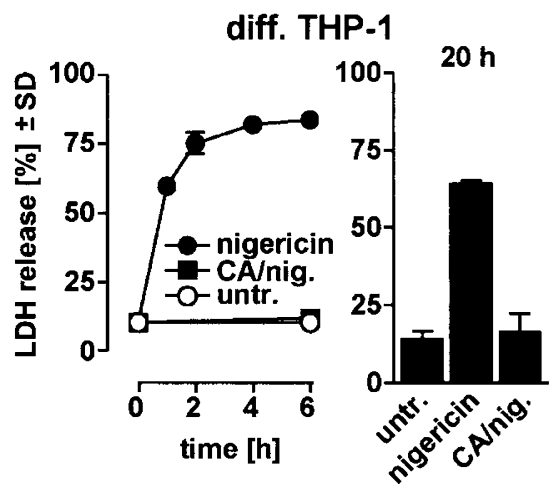


nigericin-triggered cell death in THP-1 cells. While the broadrange serine protease inhibitor leupeptin, the caspase-3-like protease inhibitor zDEVD-cmk and the cathepsin D inhibitor pepstatin A had no protective effect, the calpain inhibitor AcLeu-Leu-Asn aldehyde (ALLN) diminished nigericin-induced death by half (Figure 4a). Notably, ALLN has been shown to also inhibit lysosomal cysteine proteinases, including cathepsins B and L. ${ }^{24}$ The cathepsin B inhibitor CA-074-Me, a methylated prodrug that is cleaved by esterases in the cytoplasm, ${ }^{36}$ completely prevented death of THP-1 cells as seen with zVAD-fmk (Figures $3 b$ and $4 a$ ).

A comparison of the concentration-response curves of zVAD-fmk and CA-074-Me in nigericin-treated THP-1 cells showed that the $\mathrm{IC}_{50}$ for $\mathrm{CA}-074-\mathrm{Me}$ was $9.5 \mu \mathrm{M}$, and the $\mathrm{IC}_{50}$ for zVAD-fmk was $47.5 \mu \mathrm{M}$ (Figure $4 \mathrm{~b}$ ). Additionally, the slope was found to be extremely steep only in the case of zVAD-fmk, which indicates that a threshold concentration must be reached to achieve protection. Despite the fact that more than $80 \%$ of the cells died within $2 \mathrm{~h}$, we extended the observation time to later time points using both monocytic THP-1 cells and PMA-differentiated adherent THP-1 cells, a commonly used macrophage model. We observed that in both cases, cells were fully protected up to $6 \mathrm{~h}$ (Figure $4 \mathrm{c}$, d). At $20 \mathrm{~h}$, THP-1 monocytic cells were still partially protected (Figure 4c), and differentied THP-1 cells, which died with similar kinetics, were fully protected at this late time point (Figure 4d). Clonogenicity assays over a longer period were unsuccessful because of the reported antimitotic potential of cathepsin B inhibition. ${ }^{37}$ Overall, these inhibitor experiments indicate that cathepsin $B$ is a key player in nigericin-induced necrosis in THP-1 cells.

\section{Nigericin increases cytosolic cathepsin B activity and stimulates translocation of cathepsin $B$ into the cytoplasm}

We next addressed the question whether an increase in cytosolic cathepsin B activity could be measured after nigericin treatment in THP-1 cells. For the extraction of cytosolic samples with minimal lysosomal contamination, we used a modified digitonin extraction method. ${ }^{24}$ The optimization of the lysis parameters is shown in Figure 5a. We determined that at $50 \mu \mathrm{g} / \mathrm{ml}$ digitonin (Figure $5 \mathrm{a}$, dotted line), the $\mathrm{LDH}$ leakage was maximal and the protein extraction nearly complete, but the rupture of lysosomes was only minimal. We generated samples from nigericin-treated and untreated THP-1 cells using these conditions, and found that $30 \mathrm{~min}$ after nigericin treatment, the extractable cytosolic cathepsin B activity was significantly increased by about twofold (Figure 5b). Conversely, samples from nigericinstimulated THP-1 cells pretreated with either CA-074-Me or zVAD-fmk had only a barely detectable cleavage activity, which did not increase significantly after 30 min (Figure 5b). The twofold increase in cathepsin B activity is in the same range as described previously for TNF-treated tumor cell lines. ${ }^{24}$ Since nigericin-induced cell death is very rapid (maximal at $2 \mathrm{~h}$, see Figure $3 \mathrm{a}$ ), this twofold increase indicates that the cathepsin $B$ activity at the single cell level is very high at a given time point.

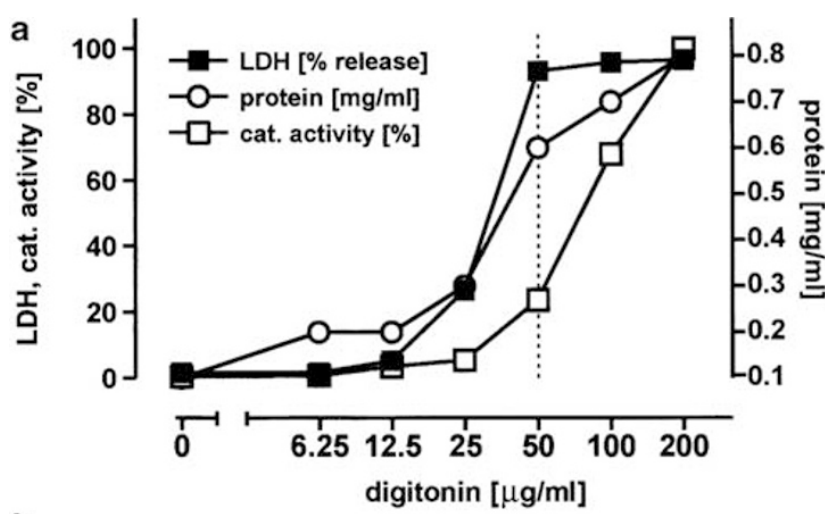

b
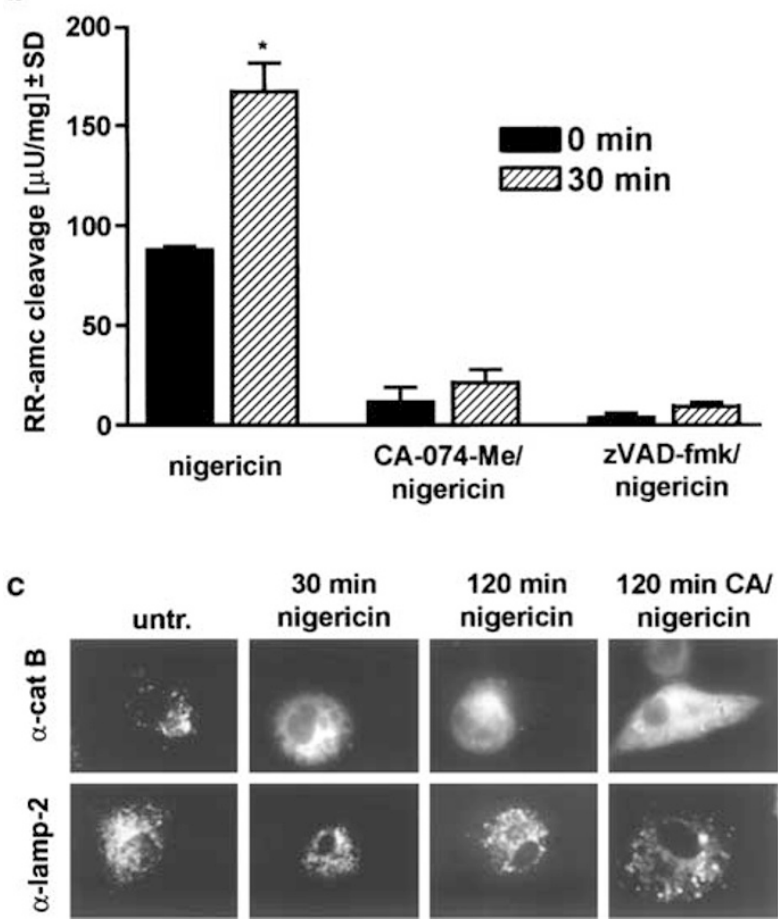

Figure 5 Nigericin treatment of THP-1 cells induces translocation of cathepsin B to the cytoplasm and cytosolic cathepsin B activity. (a) Evaluation of optimal conditions for digitonin lysis of THP-1 cells which largely avoids rupture and extraction of lysosomes (see Materials and Methods). Supernatants were assayed for LDH enzyme activity (indicator of membrane leakage, data given in percentage), for protein extraction efficiency (Pierce assay, $\mathrm{mg} / \mathrm{ml}$ protein) and for total cathepsin (cat.) activity (cleavage of ZFR-amc, data given in percentage). (b) THP-1 cells ( $10^{6}$ cells/sample) were preincubated with $100 \mu \mathrm{M}$ of either CA074-Me or ZVAD-fmk, or left untreated, and then treated with $20 \mu \mathrm{M}$ nigericin for $30 \mathrm{~min}$. Cytosolic samples were generated as described in (a) with a concentration of $50 \mu \mathrm{g} / \mathrm{ml}$ digitonin, and samples were assayed with a zRRamc cleavage assay specific for cathepsin $B$. Triplicate determinations $(\mathbf{a}, \mathbf{b})$ and an ANOVA followed by the Tukey multiple comparison test were performed with all experimental groups (b); $30 \mathrm{~min}$ versus $0 \mathrm{~min}, P<0.01$ was considered significant. (c) Differentiated adherent THP-1 cells were treated with nigericin with or without CA-074-Me as in (a), processed for immunohistochemistry, and stained with anti-cathepsin B monoclonal antibody or monoclonal anti-lamp-2 antibody as described in 'Materials and Methods'. Specimens were reviewed using a high-resolution Zeiss AxioCam CCD camera mounted on an inverted Zeiss Axioplan microscope, original magnification of the pictures: $\times 100$. untr., untreated

Immunohistochemistry of differentiated THP-1 cells using an anti-cathepsin $\mathrm{B}$ antibody showed a pronounced punctuate staining, in agreement with its known lysosomal localization 
(Figure 5c, left upper panel). Translocation of cathepsin B to the cytoplasm was observed as early as $30 \mathrm{~min}$ after nigericin treatment, and at later times the staining was entirely diffuse/ cytoplasmatic. Notably, in CA-074-Me-treated cells, which were protected against nigericin-triggered cell death (Figure 4), the translocation of cathepsin B occurred to a comparable extent. Similarly, when cells were preloaded for $1 \mathrm{~h}$ with a lysotracker, we observed a punctuate staining that disappeared $30 \mathrm{~min}$ after nigericin treatment with or without CA074-Me (data not shown). Using an antibody against the lysosomal membrane protein lamp-2 that is known to stain late endosomes as well as lysosomes, we found a punctuate staining similar to the cathepsin B staining which did not recede during nigericin-induced cell death, indicating that the lysosomal membrane compartment was still intact. Collectively, this is evidence for a prominent nigericin-induced lysosomal leakage of cathepsin B and other lysosomal components in the absence of obvious lysosomal rupture, which corroborates the detected early increase in cytoplasmatic cathepsin $\mathrm{B}$ activity.

\section{Cathepsin B inhibition by CA-074-Me prevents nigericin-mediated caspase-1 activation}

It is known that active caspase- 3 can be recovered from supernatants of apoptotic cells. ${ }^{38}$ Since THP-1 cells are rapidly killed by necrosis after nigericin treatment in a cathepsin B-dependent fashion and the amount of processed caspase-1 in cell lysates was not extensive (Figure 1d), we reasoned that processed caspase-1 might be predominantly in the extracellular compartment. Using the antibody directed against the prodomain of caspase-1, we found that caspase-1 and its p35/p37 intermediate cleavage fragments appeared in the extracellular compartment of nigericin-treated cells in high amounts in a time-dependent manner when we analyzed concentrated supernatant samples by Western blot (Figure $6 \mathrm{a}$, left side). Additionally, $\mathrm{a} \sim 30 \mathrm{kDa}$ fragment was observed, which is known to be an inactive fragment. ${ }^{29}$ Using an antibody raised against the p20 subunit of caspase-1, we also detected this fragment as well as a $\sim 15 \mathrm{kDa}$ degradation product (Figure 6a, lower panel). Consistent with these Western blot data, we determined that $1 \mathrm{~h}$ after nigericin treatment the extracellular caspase-1 activity was increased about fivefold, whereas the increase of extracellular caspase3-like activity was relatively small under these conditions (Figure 6b). When CA-074-Me-pretreated cells were examined, caspase-1 fragments and activity were completely absent in the supernatant (Figure 6a, b). These results also explain why only small amounts of p35/p37 caspase-1 fragments were found in the cytoplasm after nigericin treatment (Figure 1d), which were only slightly reduced upon CA-074 treatment (Figure 6c).

To rule out nonspecific inhibitory effects of CA-074 on caspase-1, we determined whether CA-074 could directly inhibit recombinant human caspase-1 activity under cell-free conditions. Whereas zYVAD-cmk and zVAD-fmk inhibited recombinant human caspase-1 activity with an $I_{50}$ of $<0.1 \mu \mathrm{M}$ for both inhibitors, CA-074 as well as its membrane-permeable analog (CA-074-Me) had no inhibitory effect a

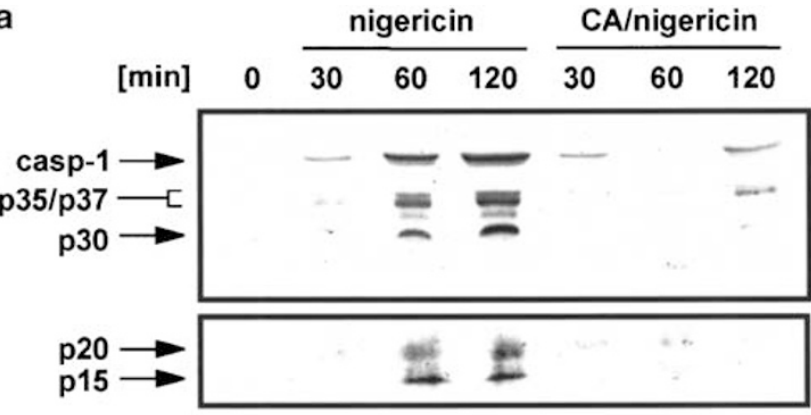

b

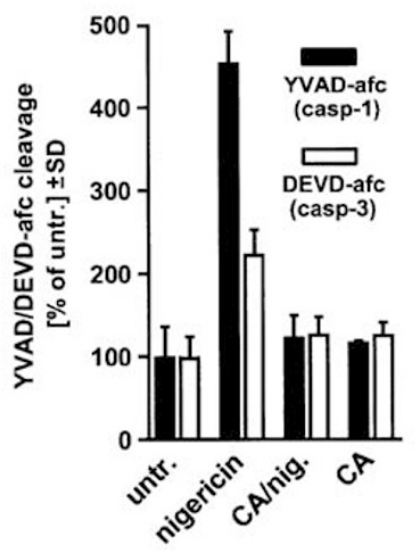

C

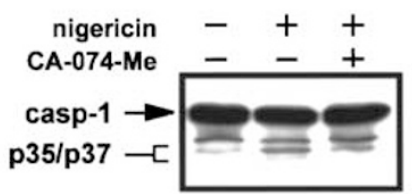

d

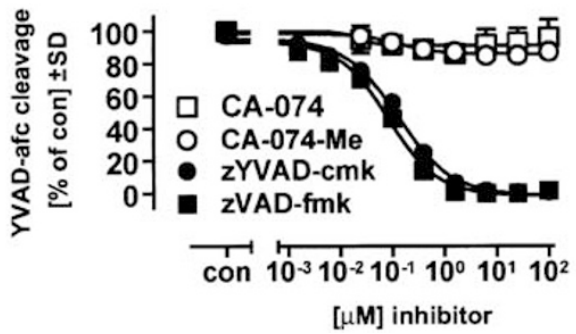

Figure 6 Inhibition of caspase-1 activation in THP-1 cells by CA-074-Me. (a) Cells were treated with $20 \mu \mathrm{M}$ nigericin in the absence of or after preincubation with $100 \mu \mathrm{M}$ CA-074-Me (CA) for the indicated times. The medium was collected, proteins were concentrated by Stratagene resin, and analyzed by Western blotting (upper panel: anti-caspase-1 prodomain antibody, lower panel: anticaspase-1 p20 antibody). Arrows indicate the precursor form of caspase-1 (p46), p35/p37 kDa intermediate active forms of caspase-1, the p20 active fragment and two additional bands (p30, p15). (b) Cells were treated as in (a), and the YVAD-afc and DEVD-afc cleaving activities of the supernatants were assessed $1 \mathrm{~h}$ later as described in 'Materials and Methods'. Untr., untreated. (c) Cells were either left untreated or treated with $20 \mu \mathrm{M}$ nigericin in the presence or absence of $100 \mu \mathrm{M} \mathrm{CA}-074-\mathrm{Me}(-1 \mathrm{~h})$ for $30 \mathrm{~min}$, and cytosolic proteins were prepared and analyzed by Western blotting using an anti-pro-domain caspase-1 monoclonal antibody. (d) Recombinant caspase- 1 (0.5 U/sample) was incubated with serial dilutions of the indicated inhibitors in $100 \mu \mathrm{l}$ caspase- 1 cleavage buffer $(50 \mathrm{mM}$ HEPES pH 7.4, 10\% sucrose, $1 \%$ CHAPS, $10 \mathrm{mM}$ DTT) and assayed for caspase-1 activity as described in 'Materials and Methods' 
on caspase-1 activity even in excess at $100 \mu \mathrm{M}$ (Figure 6d). Thus, the block of nigericin-induced caspase- 1 activation by CA-074-Me must be occurring upstream of caspase-1 itself.

\section{Cathepsin B inhibition blocks nigericin-induced IL-18 maturation}

We next addressed whether IL-18 maturation was affected by CA-074-Me. Both intracellular and released IL-18 levels were determined, and the values were combined to give total levels of mature IL-18 (Figure 7a). We found that the total production of mature IL-18 after nigericin treatment was prevented when cells were preincubated with CA-074-Me, arguing that cathepsin $B$ activity is strictly required for caspase-1-mediated IL-18 maturation.

We also asked whether the high levels of mature IL-18 in the medium after nigericin treatment could have been generated outside the cells, since both processed caspase-1 and pro-IL18 are located in the extracellular compartment after nigericintriggered necrosis has occurred (Figures 1c and 6a). However, when the caspase- 1 substrate pro-IL-1 $\beta$ was added to the medium while cells were incubated with nigericin, we could not detect any cleavage of this cytokine when a concentrated supernatant was used for Western blotting (Figure $7 \mathrm{~b}$, left side). Recombinant caspase-1 as a positive control cleaved pro-IL-1 $\beta$ in an optimized reducing caspase-1 cleavage buffer, but not in normal RPMI medium (Figure 7b, right side). Substantiating the inactivity of extracellular caspase-1 under cell culture conditions, we determined that caspase-1 from supernatants was biochemically active in the YVAD-afc cleavage assay only when the optimized reducing reaction buffer was used (Figure $6 \mathrm{~b}$ ), but was inactive in RPMI medium alone (data not shown). Additionally, it was observed that mature IL-18 levels peaked within the cells at the $30 \mathrm{~min}$ time point, well before its release into the supernatant was found to be maximal (data not shown) and prior to the peak of necrosis (Figure 3a). Overall, these results argue that cathepsin B-dependent caspase-1 processing after nigericin treatment leads to a rapid maturation of IL-18 inside the cells, which is then released because of ensuing necrosis.

We next confirmed and extended the above findings that cathepsin B mediates IL-18 processing and necrosis. First, we used stable THP-1 cell lines overexpressing either antisense cDNA directed against cathepsin B mRNA, or the natural inhibitor of cathepsins, cystatin $A$. In both instances, we observed an approximately $50 \%$ decrease in IL-18 levels (Figure 7c, left side), and cell death was reduced to a similar extent (data not shown). Second, we found a prominent block of nigericin-triggered IL-18 production by preincubation of primary peritoneal mouse macrophages as well as of primary human blood monocytes with CA-074-Me or zYVAD-cmk (Figure 7c, right side). As described previously, ${ }^{11}$ nigericin alone also induced cell death in primary peritoneal macrophages from FVBN mice, which was of obvious necrotic morphology (data not shown) exactly as shown for THP-1 cells (Figure $3 b$ ). Moreover, peritoneal macrophage cell death was suppressed when cells were preincubated with the
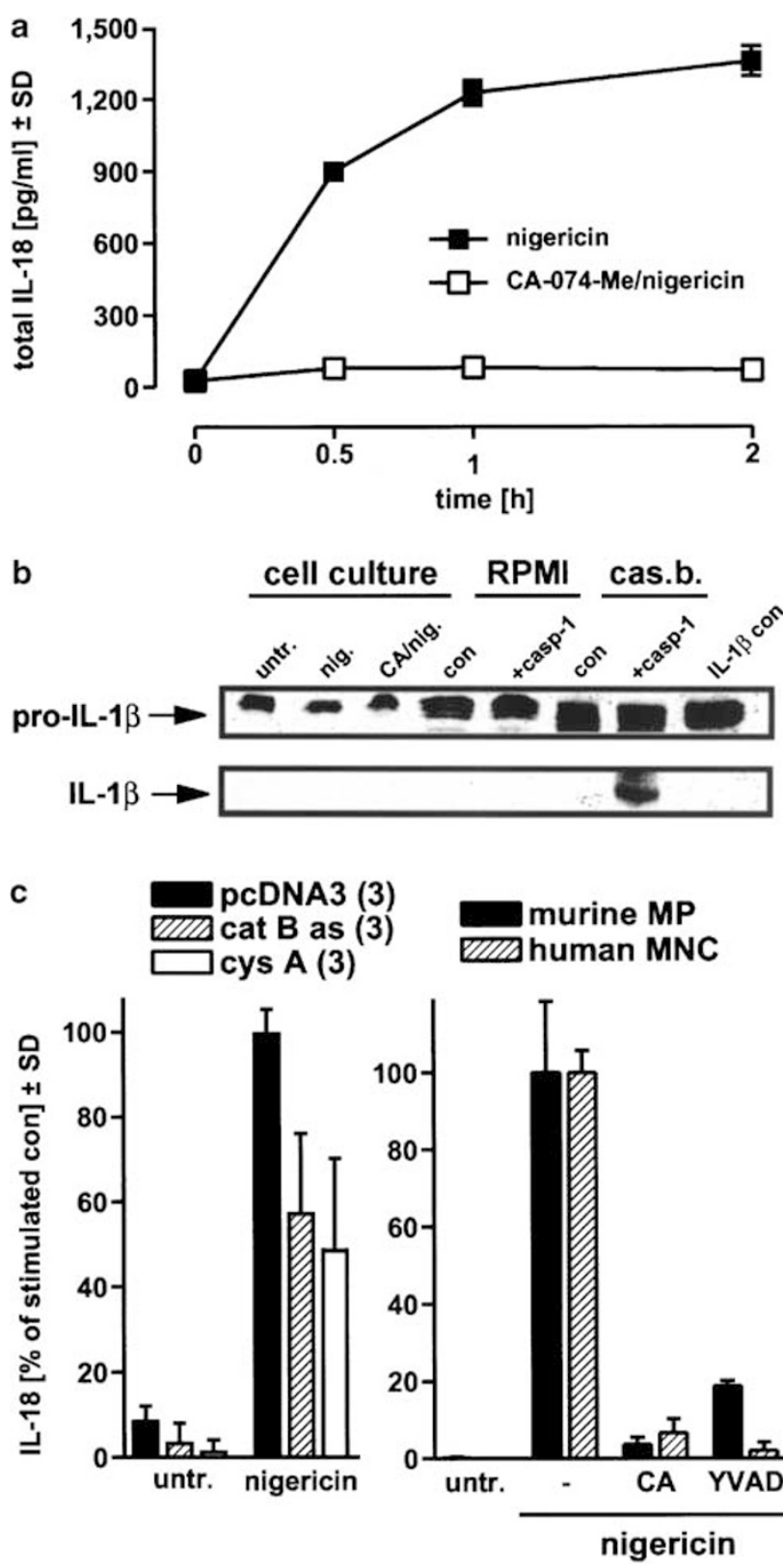

Figure 7 Inhibition of IL-18 maturation by cathepsin inhibition in THP-1 cells, stable THP-1 lines and primary monocytes/macrophages. (a) THP-1 cells were treated with $20 \mu \mathrm{M}$ nigericin in the presence or absence of $100 \mu \mathrm{M} \mathrm{CA}-074-\mathrm{Me}$. The amount of IL-18 from both medium and cytosol was combined and designated as total IL-18. (b) Recombinant human IL-1 $\beta\left(1 \mu \mathrm{g} / \mathrm{well}, 10^{6} \mathrm{cell} / \mathrm{ml}\right)$ was used to assay for extracellular caspase- 1 activity (left side, treatments as in (a), incubation $2 \mathrm{~h}$, untr., untreated). Additionally, the same amount of $\mathrm{IL}-1 \beta$ was incubated in RPMI buffer (middle part) or in caspase-1 cleavage buffer devoid of cells (cas.b.., right side), in the absence or presence of recombinant human caspase-1 (2 U/sample). All samples were concentrated with Stratagene resin, and subjected to Western blot analysis using an anti-IL-1 $\beta$ antibody (extreme right lane: control IL-1 $\beta$ ). (c) Left panel. Stable THP-1 cell lines overexpressing either anti-cathepsin B antisense cDNA or the cathepsin inhibitor cystatin A, plus the vector control lines were exposed to $20 \mu \mathrm{M}$ nigericin, and released IL-18 was determined $2 \mathrm{~h}$ later (left side, results of three independent lines were pooled). Right panel. Primary murine peritoneal macrophages (MP) and primary human MNC containing $\sim 20 \%$ monocytes were incubated with CA-074-Me or zYVADcmk $(100 \mu \mathrm{M},-2 \mathrm{~h})$ and nigericin $(20 \mu \mathrm{M})$, and the released IL-18 was quantitated after $2 \mathrm{~h}$. For comparison, the nigericin-stimulated amount of IL-18 was set at $100 \%$ (absolute IL-18 levels were between 300 and $1000 \mathrm{pg} / \mathrm{ml}$ in all experiments). Values are means $\pm S D$ from triplicate determinations 
cathepsin B inhibitor CA-074-Me (LDH release after $3 \mathrm{~h}$ : control $=13.8 \pm 0.9 \% ; \quad$ nigericin $=67.9 \pm 1.3 \%$; $\quad$ CA-074Me+nigericin $=38.1 \pm 0.6 \%$ ), but not when cells were exposed to zDEVD-cmk or zYVAD-cmk. Thus, we demonstrate that cathepsin B-dependent IL-18 activation and necrosis are also seen when approaches other than pharmacological inhibitors are used, and furthermore that these phenomena are observed in primary cells as well as in cell lines.

\section{Calpain and proinflammatory caspases as potential direct targets of cathepsin $B$}

Having established that cathepsin B is an upstream activator in nigericin-induced caspase-1 activation and necrosis, we next addressed the possible targets of cathepsin. Since calpain has been frequently implicated in necrosis ${ }^{39}$ and the calpain/cathepsin inhibitor ALLN partially rescued cells from necrosis (Figure 4a), we first checked the protein status of calpain upon nigericin treatment. Western blotting demonstrated that the small calpain subunit was processed to its active p18 fragment via the p23 intermediate ${ }^{40,41}$ in THP-1 cells exposed to nigericin, and this cleavage was prevented by preincubation with CA-074-Me (Figure 8a, inset). When we applied a panel of calpain inhibitors, we found that ALLN and zVF (which also inhibit cathepsin B) ${ }^{24}$ suppressed nigericininduced cell death by $50 \%$, whereas two more specific inhibitors (zLLL, PD150606) ${ }^{42}$ exerted no significant protection. We thus infer that calpain is activated downstream of cathepsin B in nigericin-treated THP-1 cells, but the activation of this protease appears to play a minor role in cell death execution.

Recently, two groups addressed possible direct caspase activation by cathepsin $B$ in cell-free systems, showing that the murine proinflammatory caspase- 11 is readily cleaved by cathepsin $\mathrm{B},{ }^{21,22}$ but ruling out human apoptosis-related caspases as direct targets. ${ }^{43}$ We therefore analysed whether in vitro-translated human proinflammatory caspases 1, 4 and 5 and murine caspase-11 (positive control) would be processed in a cell-free screen using purified human cathepsin $\mathrm{B}$ at neutral and acidic $\mathrm{pH}$ (Figure $8 \mathrm{~b}$ ). We found that while caspase- 11 is readily processed by cathepsin $B$ as described at neutral and acidic $\mathrm{pH}$ to a similar extent, ${ }^{21,22}$ caspase -1 and -4 are cleaved by cathepsin $\mathrm{B}$ only at acidic $\mathrm{pH}$ (Figure 8b). Recalling that cells strongly acidify after exposure to nigericin, ${ }^{12}$ it is possible that direct cleavage of proinflammatory human caspases by cathepsin B can occur in these circumstances. Apparently, the size of the cleavage fragments of caspase-1/-4 generated by cathepsin $B$ is different from the active fragments derived from caspase-1/4 self-processing. However, given the fact that cathepsin $B$ can cleave a protein at sites different from caspase cleavage sites while still generating fully active fragments (e.g. Bid ${ }^{43}$ ), it is possible that cathepsin B can directly cleave caspase-1/-4, which may trigger further caspase-1 activation by selfprocessing (or processing by caspase-4). Further work is needed to definitively map the cleavage sites on caspase-1/-4 by cathepsin B, test for the activity of these fragments, and investigate whether any of these caspases are direct targets of cathepsin B in living cells.
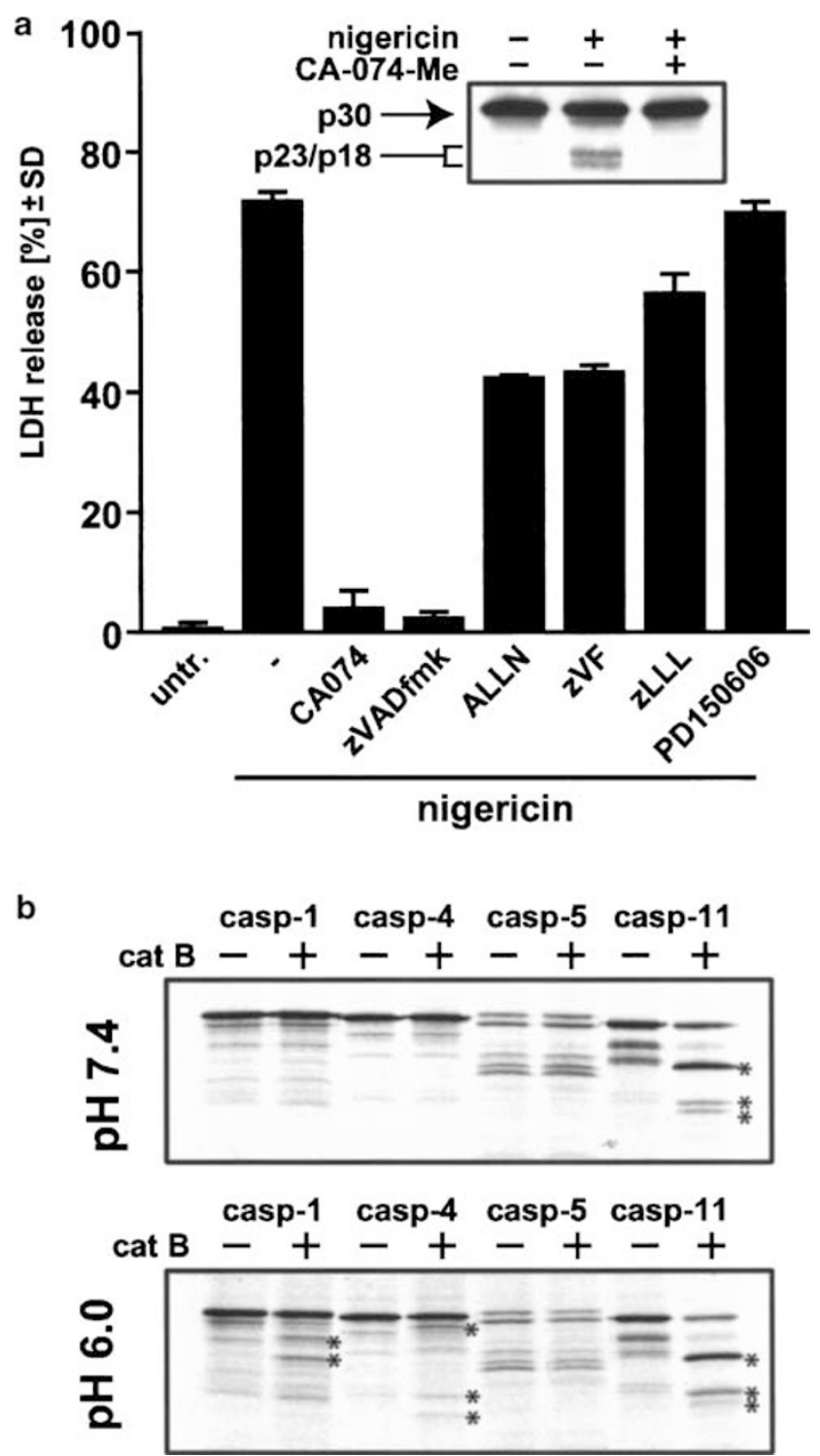

Figure 8 Calpain and proinflammatory caspases as potential targets of cathepsin B. (a) THP-1 cells were either left untreated or treated with $20 \mu \mathrm{M}$ nigericin in the presence or absence of $100 \mu \mathrm{M} \mathrm{CA}-074-\mathrm{Me}$ for $1 \mathrm{~h}$, and cytosolic proteins were analyzed by Western blotting using an anti-calpain monoclonal antibody directed against the small subunit (inset). The cytoprotective potential of various calpain inhibitors in comparison with zVAD-fmk and CA-074-Me was evaluated by preincubating THP-1 cells for $1 \mathrm{~h}$ with the indicated inhibitors $(100 \mu \mathrm{M})$, followed by $2 \mathrm{~h}$ incubation with nigericin $(20 \mu \mathrm{M})$. Values are given as means $\pm S D$ from triplicate determinations. (b) Cell-free cleavage of proinflammatory caspases by purified human cathepsin B. ${ }^{35} \mathrm{~S}$-methionine-labeled caspases 1, 4, 5 and 11 were incubated with purified human cathepsin B in cleavage buffer at the indicated $\mathrm{pH}$. The resulting cleavage products were analyzed by SDS-PAGE and autoradiography. The stars mark the cleavage fragments generated (caspase-1, 40/37 kDa; caspase-4, 43/31/27 kDa; caspase$11,37 / 31 / 29 \mathrm{kDa}$. Note that the myc tag adds $2 \mathrm{kDa}$ to the procaspase molecular weight)

\section{Discussion}

Secondary stimuli such as ATP, nigericin and other bacterial pore-forming toxins have been frequently used to boost IL-1 $\beta$ release following prestimulation of monocytes or macrophages with LPS. ${ }^{11,12,14,31,44}$ The LPS-priming step allows 
the synthesis of pro-IL-1 $\beta$ and may also provide crucial signals for these secondary stimuli to achieve their effect. In this study, we revealed that in the case of nigericin, the LPS priming step is not necessary, since nigericin alone was sufficient to induce both caspase- 1 activation and mature IL18 release (Figures 1, 2 and 7). Nigericin also promoted IL-18 release in macrophages from an LPS-unresponsive mouse strain, confirming that nigericin exerts its action independent of LPS signaling (Figure 2). The degree of the IL-18 stimulating effect in THP-1 cells is very similar to what was observed in freshly isolated human monocytes and mouse primary peritoneal macrophages, ${ }^{45}$ suggesting that the signaling pathway mediating the production of both cytokines is well preserved in THP-1 cells. Since nigericin alone induced IL-18 maturation in primary mouse macrophages and human blood monocytes, this phenomenon is not restricted to THP-1 cells or cell lines.

The common feature of the known secondary stimuli is that they all induce cell death concomitant with the release of IL-1 $\beta$ and IL-18. ${ }^{11,12,45}$ One important issue is the mode of cell death that these secondary stimuli induce. It has been reported that nigericin induces either apoptosis ${ }^{31,46}$ or necrosis, ${ }^{17}$ and this discrepancy could be due to different cell types, different time schedules of treatment, or due to the diverse cell death assays applied. In THP-1 cells, nigericin clearly triggers a very rapid necrotic cell death that shows no sign of apoptotic features. It is important to note that the frequently used broad-spectrum caspase inhibitor zVAD-fmk is a potent cathepsin $\mathrm{B}$ inhibitor, ${ }^{35}$ and evidence for the contribution of caspase activity to cell death or for apoptosis based exclusively on the use of this substance is therefore questionable. Does caspase-1 activation and subsequent IL$1 \beta$ and IL-18 maturation contribute to necrotic cell death? For instance, cell death induced by ATP, a secondary stimulus that also boosts IL- $1 \beta$ production in monocytes, appears to be caspase-1-independent. ${ }^{47,48}$ Consistent with these results, we revealed that although the caspase-1 specific inhibitor zYVAD-cmk effectively blocks the production of mature IL-18 in THP-1 cells, it does not protect cells from nigericin-induced necrosis (Figure $1 \mathrm{~b}$ versus Figure $3 \mathrm{~b}$ ). This is supported by the finding that $z Y V A D-c m k$ effectively inhibits the release of mature IL-18, but not pro-IL-18 (Figure 1b, c). These findings indicate that caspase- 1 activation and necrosis are two separate pathways triggered by nigericin as summarized in Figure 9.

Is the release of mature IL-18 after nigericin treatment simply the consequence of cell rupture, and is cell death therefore a prerequisite for the production of this cytokine? It is important to note that the release mechanism of mature IL-18 is entirely unknown. ${ }^{3}$ We found that the cathepsin B inhibitor CA-074-Me was able to inhibit both nigericin-induced necrosis and caspase- 1 activation. As there are no known reagents that can protect cells from nigericin-induced necrosis without affecting caspase-1 activation, we cannot address the probability that a proportion of caspase- 1 may be activated as a result of necrosis. Yet, the release of IL-1 $\beta$ and IL-18 triggered by these secondary stimuli in several systems occurred concurrently with the release of other cellular contents such of $\mathrm{LDH}^{11,12,45}$ Accordingly, we observed a close link between the kinetics of mature IL-18 release, the

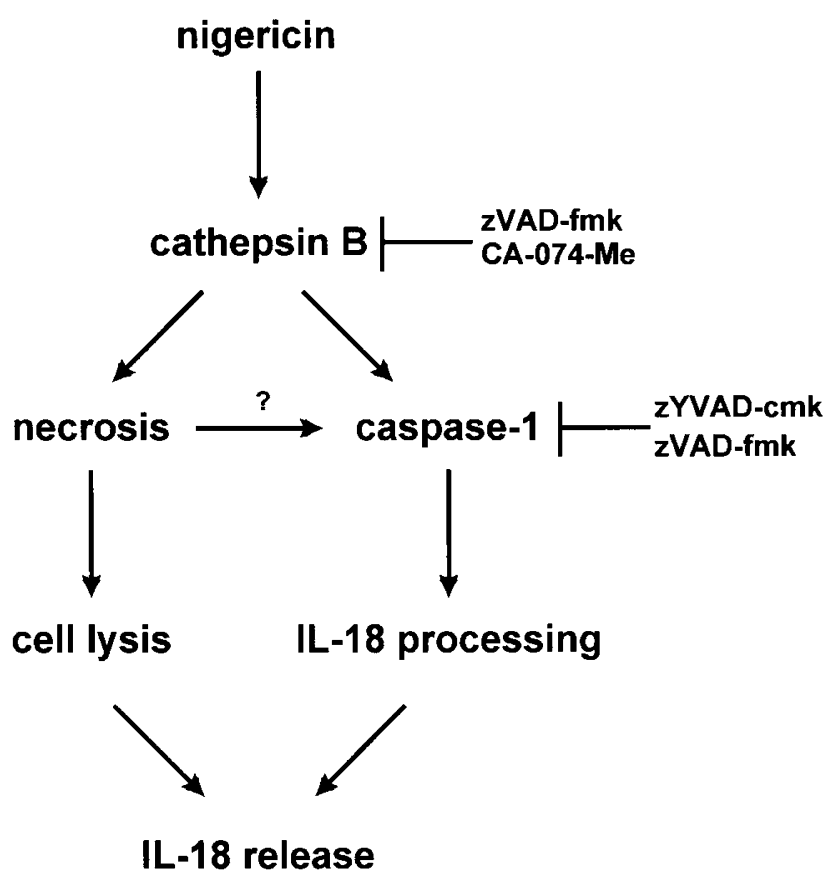

Figure 9 Model of nigericin-induced necrosis and caspase-1 activation. Nigericin triggers necrosis and caspase-1 activation through a cathepsin Bdependent pathway. The necrosis pathway is independent of caspase-1 activation, and may act upstream of the caspase- 1 activation pathway (indicated by a question mark). IL-18 maturation occurs upon caspase-1 activation; however, IL-18 release is largely dependent on the extent of necrosis. The caspase inhibitors ZYVAD-cmk and ZVAD-fmk block caspase-1 activation; in addition, zVAD-fmk can also inhibit cathepsin $B$ activity when used at high concentration. CA-074-Me specifically inhibits cathepsin B activity without inhibiting caspase-1 processing activity

appearance of activated caspase-1 in the supernatant and $\mathrm{LDH}$ release (Figures $1 \mathrm{~b}, 3 \mathrm{a}, 6 \mathrm{a}$ ). Additionally, we ruled out the possibility that IL-18 might be cleaved outside the cells as a cell culture phenomenon (Figure $7 c$, additional data in text). Overall, our experiments therefore support the following model (Figure 9). Nigericin leads to lysosomal leakage, translocation and activation of cathepsin B, which simultaneously activates both caspase- 1 and a necrosis. As pro-IL18 is present in the cytoplasm in high amounts, it is readily processed by active caspase-1. Owing to ensuing cell rupture, mature IL-18 as well as processed caspase- 1 fragments then appear in the supernatant.

The lysosomal proteases of the cathepsin family have been previously implicated in a number of important cellular processes such as protein degradation, antigen processing and the execution of cell death. ${ }^{49-53}$ Recently, evidence has emerged that the activation and translocation of cathepsin $B$ is crucial in certain models of TNF-triggered apoptosis ${ }^{24,25,54}$ and of TWEAK-induced cell death. ${ }^{26}$ Notably, the involvement of cathepsins in macrophage activation was reported long before caspase-1 was described. A rise in intracellular cathepsin activity after activation of peritoneal mouse macrophages and also during differentiation of human blood monocytes was noted long ago, ${ }^{55}$ and inflammatory stimuli such as LPS or interferon- $\gamma$ are also known to enhance cathepsin activity in THP-1 cells. ${ }^{56}$ In none of the above 
studies were cathepsin inhibitors or other tools used to test for the involvement of cathepsins in caspase-1 activation.

At present, the possible molecular mechanisms by which nigericin induces necrosis and activates caspase- 1 via cathepsin B remain speculative. Cathepsin B may activate part of the signaling cascade employed by TLR-4 or converge with it at any level. ${ }^{57}$ For example, cathepsin B may cleave proinflammatory caspases directly as described for the murine caspase-11 under cell-free conditions, ${ }^{21,22}$ and in our present study in which human caspases 1 and 4 are processed in vitro by cathepsin B (Figure 8b). Our preliminary evidence also indicated that nigericin induces calpain processing downstream of cathepsin B, but only calpain inhibitors with cathepsin B-inhibiting potential partially block necrotic cell death. At most, calpain might have a minor role in necrosis, and more work is needed to establish whether or not calpain contributes to IL-18 maturation.

In conclusion, our study provides the first evidence that cathepsin B activity is required for necrosis, caspase-1 activation and IL-18 generation triggered by a toxin in monocytic cells. Besides this new link between caspases and cathepsin B in a cell model, this finding has further biological implications with regard to infection. Nigericin is produced by mycobacteria and causes cytolysis of monocytes and macrophages, which is presumably an attempt by the pathogen to dampen innate immunity. However, our work implies that in these circumstances monocytes have an LPSindependent mechanism in place to produce and release significant amounts of mature IL-18, which is known to play a pivotal role in boosting host immune defense against various infectious microbes through its interferon- $\gamma$-inducing activity (reviewed by Nakanishi et al. ${ }^{3}$ ).

\section{Materials and Methods}

\section{Reagents}

Nigericin, Digitonin, LPS (Escherichia coli serotype 055:B5), Leupeptin, and PMA were purchased from Sigma. The inhibitors ALLN, z-Val-Phealdehyde (zVF), z-Leu-Leu-Leu-aldehyde (zLLL), zYVAD-, zDEVD-fmk, zVAD-fmk, L-trans-epoxysuccinyl-lle-Pro-OH (or OMe) propylamide (CA074 or CA-074-Me), pepstatin A, and the protease substrates $\mathrm{N}$-acetylTyr-Val-Ala-Asp-7-amino-4-trifluoromethylcoumarin (zYVAD-afc), zDEVDafc (z-Asp-Glu-Val-DL-Asp-7-amino-4-trifluoromethylcoumarin), z-ArgArg-7-amino-4-methylcoumarin (zRR-amc) and z-Phe-Arg-7-amino-4methylcoumarin (zFR-amc) were obtained from Bachem AG (Bubendorf, Switzerland). Pefablock ${ }^{\circledR}$ was bought from Hoffmann-La Roche AG (Basel, Switzerland). The calpain inhibitor PD150606 and purified human cathepsin B were from Calbiochem (La Jolla, CA, USA). Recombinant human caspase-1 (active) protein was from Chemicon (Temecula, CA, USA), and purified human pro-IL-1 $\beta$ was made in Escherichia coli using the GST-PreScission Protease System from Amersham Biosciences (Uppsala, Sweden). The dyes Hoechst-33342 and SYTOX were bought from Molecular Probes (Eugene, OR, USA). The human IL-1 $\beta$ ELISA kit was purchased from R\&D systems (Minneapolis, MN, USA). The human and mouse IL-18 ELISA kits were from MBL (Nagoya, Japan) and used as described in the manufacturers instructions. The mouse monoclonal antibody for caspase-1 was a gift from Dr. J. Yuan (Harvard Medical School, Boston, USA), and the antibody against the small subunit of human calpain was bought from Chemicon (MAB3083). The antibodies against human IL-18 (sc-6177), human IL-1 $\beta$ (sc-7884) and caspase-1 (anti-prodomain: sc-622, anti-p20: sc-1780) were from Santa Cruz Biotechnology (Santa Cruz, CA, USA). The anti-cathepsin B antibody (mouse monoclonal IM27L) was from Oncogene (San Diego, CA, USA), the anti-Lamp-2 antibody (mouse monoclonal 555803) was from BD PharMingen (Becton Dickinson, NJ, USA), and the secondary anti-mouse FITC-coupled antibody was from Jackson Laboratories (Bar Harbor, MA, USA).

\section{Culture of THP-1 cells and cell death assays}

THP- 1 cells were maintained in RPMI 1640 supplemented with 10\% heatinactivated FCS and $10 \mu \mathrm{g} / \mathrm{ml}$ penicillin/streptomycin in a humidified atmosphere at $37^{\circ} \mathrm{C}$ and $5 \% \mathrm{CO}_{2}$. Cells were passaged every 3-4 days in a ratio of $1: 10$. For experiments, cells were centrifuged $\left(500 \mathrm{~g}, 4^{\circ} \mathrm{C}\right.$, $3 \mathrm{~min})$, resuspended in medium, plated in 96-well plates $(100 \mu \mathrm{l}$ cell suspension, $10^{5}$ cells/well) or $35 \mathrm{~mm}$ dishes ( $3 \mathrm{ml}$ cell suspension, $3 \times 10^{6}$ cells/dish) and incubated with the compounds indicated. For macrophage differentiation, THP1 cells were incubated for $72 \mathrm{~h}$ with $100 \mathrm{nM}$ PMA. To determine necrosis and apoptosis of THP-1 cells, the cultures were stained as described in detail ${ }^{58}$ with a mixture of the membrane permeable DNA dye H-33342 $(500 \mathrm{ng} / \mathrm{ml})$ and the membrane impermeable DNA dye SYTOX ( $500 \mathrm{nM})$. Necrotic and apoptotic cells were photographed using a Zeiss epifluorescence microscope with an attached Nikon Coolpix digital camera. Cytotoxicity was quantitated by measurement of lactate dehydrogenase (LDH). ${ }^{59}$ THP-1 cells were centrifuged briefly, and the $\mathrm{LDH}$ activity was determined in both cleared culture supernatants (S) and in the cell pellet $(P)$ after lysis with an equal volume of RPMl containing $0.1 \%$ Triton $\mathrm{X}-100$. The cytotoxicity was calculated as percentage LDH release by the ratio of $\mathrm{P} /(\mathrm{S}+\mathrm{P})$.

\section{Generation of stable THP-1 cell lines}

We used a previously described human cathepsin B-antisense construct derived from the pcDNA3(+) vector, ${ }^{24}$ and we further constructed a cystatin A-containing pcDNA3(+) vector. Human cystatin A was cloned from mRNA derived from THP-1 cells by RT-PCR and ligated into the pcDNA3.1(+) vector between Hindll and BamHI sites. Scal-linearized vectors were electroporated into THP-1 cells at $220 \mathrm{~V}$ and $960 \mu \mathrm{F}$. Stable lines were selected from surviving colonies after 3 weeks of culture in $900 \mu \mathrm{g} / \mathrm{ml} \mathrm{G418}$ and maintained in G418-containing medium.

\section{Western blot analysis and immunocytochemistry}

THP-1 S100 lysates were prepared by resuspending cells in a hypotonic buffer containing $25 \mathrm{mM}$ HEPES pH 7.5, $2 \mathrm{mM}$ EDTA, 0.1\% 3-([-3cholamidopropyl) dimethylammonio]-1-propanesulfonic acid (CHAPS), $20 \mu \mathrm{g} / \mathrm{ml}$ leupeptin, $2 \mu \mathrm{g} / \mathrm{ml}$ antipain, and $2 \mathrm{mM}$ phenylmethylsulfonyl fluoride (PMSF) at $10^{8} \mathrm{cells} / \mathrm{ml}$, and freeze/thawing three times in liquid nitrogen. The nuclei and cell debris were removed by centrifugation (20 min, $14000 \times g, 4^{\circ} \mathrm{C}$ ). The post-nuclear supernatants were further cleared by centrifugation at $100000 \times g(55000 \mathrm{rpm}$, TLA100.1 rotor, Beckman) for $60 \mathrm{~min}$ at $4^{\circ} \mathrm{C}$. To concentrate secreted IL-18 in the cell culture medium, $40 \mu \mathrm{l}$ of StrataClean resin (Stratagene, La Jolla, CA, USA) was added to $1 \mathrm{ml}$ of medium sample. The resin-bound protein samples were recovered by centrifugation, washed once with PBS, and subjected to SDS-PAGE separation. Western blot analysis was carried out as described previously. ${ }^{5}$

For immunocytochemistry, adherent THP1 cells differentiated on round cover slides $\left(2 \times 10^{5}\right.$ cells/well, 24-well plates) were used. Cells were fixed 
with ice-cold methanol, rehydrated with PBS, and postfixed with $4 \%$ buffered paraformaldehyde. The specimens were stained using anticathepsin B antibody $(2 \mu \mathrm{g} / \mathrm{ml})$ or anti-Lamp-2 antibody $(1 \mu \mathrm{g} / \mathrm{ml})$ and a secondary anti-mouse FITC-coupled antibody (1:500). Pictures were recorded using a high-resolution Zeiss AxioCam CCD camera mounted on an inverted Zeiss Axioplan microscope.

\section{Isolation and culture of peritoneal mouse macrophages and human blood mononuclear cells (MNC)}

Specific pathogen-free FVBN mice (6-8 weeks, from the in-house animal breeding unit, IMCB Singapore) or $\mathrm{C} 3 \mathrm{H} / \mathrm{HeJ}$ mice obtained from Jackson Laboratories (Bar Harbor, Maine, USA) were used. Mice were killed by cervical dislocation, the outer coat of the peritoneum was opened, and $10 \mathrm{ml}$ of ice-cold PBS was injected into the peritoneal cavity using an intravenous 18G plastic canula (Braun, Melsungen, Germany). Animals were shaken gently for about $3 \mathrm{~min}$, and the lavage liquid was transferred to $15 \mathrm{ml}$ Falcon polystyrene tubes (Becton Dickinson, NJ, USA). After centrifugation $\left(500 \times \mathrm{g}, 4^{\circ} \mathrm{C}, 3 \mathrm{~min}\right)$, cells were resuspended in RPMl 1640 medium supplemented with $10 \%$ heat-inactivated FCS and $10 \mu \mathrm{g} / \mathrm{ml}$ penicillin/streptomycin, and plated in 96-well plates $\left(2 \times 10^{5}\right.$ cells/well). After $12 \mathrm{~h}$ incubation in a humidified atmosphere at $37^{\circ} \mathrm{C}$ at $5 \% \mathrm{CO}_{2}$, the nonadherent cells were removed by medium exchange, and the adherent peritoneal macrophages were incubated as indicated in a volume of $100 \mu$.

For the preparation of MNC, heparinized blood was used. Erythrocytes were separated from MNC by one-step centrifugation using the Lymphoprep reagent (Nycomed, Oslo, Norway) according to the manufacturers' instruction. The MNC, which are known to comprise about 20\% monocytes, were plated in RPMI 1640 medium (10\% heatinactivated FCS, $10 \mu \mathrm{g} / \mathrm{ml}$ penicillin/streptomycin) on 96 -well plates $\left(10^{6}\right.$ cells/well). Incubations were done immediately in a humidified atmosphere at $37^{\circ} \mathrm{C}$ at $5 \% \mathrm{CO}_{2}$.

\section{Determination of caspase activities}

The activities of caspase- 1 and of caspase-3-like proteases were measured on microtiter plates according to the method originally described by Thornberry. ${ }^{60}$ THP-1 S100 lysates $(10 \mu \mathrm{l})$, supernatants $(50 \mu \mathrm{l})$, or recombinant caspase- $1(0.5 \mathrm{U} / \mathrm{sample})$ were diluted to a final volume of $100 \mu \mathrm{l}$ with substrate buffer (for caspase- 1 activity: $100 \mu \mathrm{M}$ fluorogenic substrate YVAD-afc in $50 \mathrm{mM}$ HEPES pH 7.4, 10\% sucrose, 1\% CHAPS, $10 \mathrm{mM}$ DTT; for caspase-3-like activity: $60 \mu \mathrm{M}$ fluorogenic substrate DEVD-afc in $50 \mathrm{mM}$ HEPES pH 7.4, $1 \%$ sucrose, $0.1 \%$ CHAPS, $10 \mathrm{mM}$ DTT). The generation of free 7-amino-4-trifluoromethylcoumarin (afc) at $37^{\circ} \mathrm{C}$ was kinetically determined over a period of $30 \mathrm{~min}$ (DEVD-afc) or $120 \mathrm{~min}$ (YVAD-afc) by fluorescence measurement (excitation: $385 \mathrm{~nm}$; emission: $505 \mathrm{~nm}$ ) using the plate reader Spectrafluor Plus (Tecan, Crailsheim, Germany). For cell supernatants and recombinant caspase-1, data are presented as percentage of control, and where applicable, the specific activities (pmol afc/(min ${ }^{*} \mathrm{mg}$ protein) or $\mu \mathrm{U} / \mathrm{mg}$ ) were calculated using the protein concentrations of THP-1 cytosolic samples as determined with the Pierce Assay (Pierce, IL, USA).

\section{Determination of cytosolic cathepsin activities}

For the extraction of cytosolic protein without disruption of lysosomes, a described digitonin extraction method ${ }^{24}$ was optimized for THP-1 cells with serial dilutions of digitonin as shown in Figure $5 \mathrm{a}$. Briefly, $10^{6} \mathrm{THP}-1$ cells in $1 \mathrm{ml} \mathrm{RPMI} \mathrm{medium} \mathrm{containing} \mathrm{10 \%} \mathrm{FCS} \mathrm{were} \mathrm{centrifuged} \mathrm{(} 3 \mathrm{~min}$, $3000 \times g, 4^{\circ} \mathrm{C}$ ) in $1.5 \mathrm{ml}$ Eppendorf tubes, and $300 \mu \mathrm{l}$ ice-cold digitonin extraction buffer ( $50 \mu \mathrm{g} / \mathrm{ml}$ digitonin, $250 \mathrm{mM}$ sucrose, $20 \mathrm{mM}$ HEPES $\mathrm{pH}$ $7.5,10 \mathrm{mM} \mathrm{KCl}, 1.5 \mathrm{mM} \mathrm{MgCl}$, $1 \mathrm{mM}$ EDTA, $1 \mathrm{mM}$ EGTA, $1 \mathrm{mM}$ Pefablock ${ }^{\mathbb{R}}$ ) was added immediately to the cell pellet on ice. The tubes were subsequently vortexed for $5 \mathrm{~s}$ and then kept on a shaker on ice for $10 \mathrm{~min}$. After a short centrifugation ( $1 \mathrm{~min}, 14000 \times \mathrm{g}, 4^{\circ} \mathrm{C}$ ), the resulting supernatant was quickly removed and assayed for LDH activity (see above) as the lysis parameter, for protein concentration (Pierce Assay, Pierce, IL, USA), and for cathepsin activity. The cytosolic samples $(10 \mu \mathrm{l})$ were diluted to a final volume of $100 \mu$ l with substrate buffer $(80 \mu \mathrm{M}$ fluorogenic substrate zFR-amc or zRR-amc in $50 \mathrm{mM}$ sodium acetate $\mathrm{pH}$ 6.0, 4 mM EDTA, $10 \mathrm{mM}$ DTT, 1 mM Pefablock $\left.{ }^{(\mathbb{R}}\right)$. The generation of free 7-amino-4-methylcoumarin (amc) at $30^{\circ} \mathrm{C}$ was kinetically determined by fluorescence measurement (excitation: $360 \mathrm{~nm}$; emission: $465 \mathrm{~nm}$ ) using the Spectrafluor Plus plate reader. The specific activity $(\mu \mathrm{U} / \mathrm{mg})$ was calculated as described above for the caspase activity assays.

\section{Determination of the caspase-processing activity of cathepsin B}

${ }^{35} \mathrm{~S}$-methionine-labeled C-terminal myc-tagged caspases 1, 4, 5 and 11 were prepared using the T7 Quick TnT-coupled transcription/translation systems (Promega Biotech, Madison, WI, USA). The reaction product $(2 \mu \mathrm{l})$ was incubated with $200 \mathrm{ng}$ purified human cathepsin B in $20 \mu \mathrm{l}$ cleavage buffer ( $25 \mathrm{mM}$ HEPES, either $\mathrm{pH} 7.4$ or $\mathrm{pH} 6$ as indicated, $1 \mathrm{mM}$ EDTA, $0.1 \%$ CHAPS, $10 \mathrm{mM}$ DTT, $10 \%$ sucrose) for $2 \mathrm{~h}$ at $37^{\circ} \mathrm{C}$. The resulting reaction mixtures were analyzed by $0.1 \%$ SDS-15\% PAGE and autoradiography.

\section{Statistics}

All data are given as means $\pm S D$, and statistical differences were determined using the software GraphPad Instat ${ }^{\circ}$ by one-way analysis of variance (ANOVA) followed by the Tukey multiple comparison test of the control versus other groups. $P<0.01$ was considered significant.

\section{Acknowledgements}

This work was supported by the Institute of Molecular and Cell Biology, Singapore and $A^{*} S T A R$. AGP is an adjunct staff member of the Department of Surgery, National University of Singapore. We are grateful to Dr. Junying Yuan (Harvard Medical School) for caspase-1 antibody, Dr. Jean-Paul Klein (Institut National de la Santé et de la Recherche Médicale U932, France) for THP-1 cells, Dr. Marja Jäättelä for the cathepsin B antisense plasmid, and to $\mathrm{Dr}$. C Volbracht for reviewing the manuscript.

\section{References}

1. Dinarello CA (1997) Interleukin-1. Cytokine Growth Factor Rev. 8: 253

2. Dinarello CA (1999) Interleukin-18. Methods 19: 121-132

3. Nakanishi K, Yoshimoto T, Tsutsui H and Okamura H (2001) Interleukin-18 regulates both Th1 and Th2 responses. Annu. Rev. Immunol. 19: 423-474

4. Puren AJ, Fantuzzi G and Dinarello CA (1999) Gene expression, synthesis, and secretion of interleukin 18 and interleukin $1 \beta$ are differentially regulated in human blood mononuclear cells and mouse spleen cells. Proc. Natl. Acad. Sci. USA 96: 2256-2261 
5. Lin XY, Choi MS and Porter AG (2000) Expression analysis of the human caspase- 1 sub-family reveals specific regulation of the casp- 5 gene by lipopolysaccharide and interferon- $\gamma$. J. Biol. Chem. 275: 39920-39926

6. Zheng TS, Hunot S, Kuida K and Flavell RA (1999) Caspase knockouts: matters of life and death. Cell Death Differ. 6: 1043-1053

7. Wang J and Lenardo MJ (2000) Roles of caspases in apoptosis, development, and cytokine maturation revealed by homozygous gene deficiencies. J. Cell Sci. 113: 753-757

8. Stevenson FT, Torrano F, Locksley RM and Lovett DH (1992) Interleukin 1: the patterns of translation and intracellular distribution support alternative secretory mechanisms. J. Cell Physiol. 152: 223-231

9. Wewers MD, Dare HA, Winnard AV, Parker JM and Miller DK (1997) IL-1 $\beta$ converting enzyme (ICE) is present and functional in human alveolar macrophages: macrophage IL-1 $\beta$ release limitation is ICE independent. J. Immunol. 159: 5964-5972

10. Hogquist KA, Nett MA, Unanue ER and Chaplin DD (1991) Interleukin 1 is processed and released during apoptosis. Proc. Natl. Acad. Sci. USA 88: 8485-8489

11. Perregaux D, Barberia J, Lanzetti AJ, Geoghegan KF, Carty TJ and Gabel CA (1992) IL-1 $\beta$ maturation: evidence that mature cytokine formation can be induced specifically by nigericin. J. Immunol. 149: 1294-1303

12. Perregaux D and Gabel CA (1994) Interleukin- $1 \beta$ maturation and release in response to ATP and nigericin. Evidence that potassium depletion mediated by these agents is a necessary and common feature of their activity. J. Biol. Chem. 269: 15195-15203

13. Walev I, Reske K, Palmer M, Valeva A and Bhakdi S (1995) Potassium-inhibited processing of IL-1 $\beta$ in human monocytes. EMBO J. 14: 1607-1614

14. Cheneval D, Ramage $P$, Kastelic $T$, Szelestenyi $T$, Niggli $H$, Hemmig $R$, Bachmann M and MacKenzie A (1998) Increased mature interleukin-1 $\beta$ (IL-1 $\beta$ ) secretion from THP-1 cells induced by nigericin is a result of activation of $p 45$ IL-1 $\beta$-converting enzyme processing. J. Biol. Chem. 273: 17846-17851

15. Laliberte RE, Eggler J and Gabel CA (1999) ATP treatment of human monocytes promotes caspase-1 maturation and externalization. J. Biol. Chem. 274: 36944-36951

16. Jonas D, Walev I, Berger T, Liebetrau M, Palmer M and Bhakdi S (1994) Novel path to apoptosis: small transmembrane pores created by staphylococcal alpha-toxin in T lymphocytes evoke internucleosomal DNA degradation. Infect. Immun. 62: 1304-1312

17. Warny M and Kelly CP (1999) Monocytic cell necrosis is mediated by potassium depletion and caspase-like proteases. Am. J. Physiol. 276: C717-C724

18. Bantel H, Sinha B, Domschke W, Peters G, Schulze-Osthoff $K$ and Janicke RU (2001) alpha-Toxin is a mediator of Staphylococcus aureus-induced cell death and activates caspases via the intrinsic death pathway independently of death receptor signaling. J. Cell Biol. 155: 637-648

19. Wang S, Miura M, Jung YK, Zhu H, Li E and Yuan J (1998) Murine caspase-11, an ICE-interacting protease, is essential for the activation of ICE. Cell 92: 501509

20. Martinon F, Burns K and Tschopp J (2002) The inflammasome. A molecular platform triggering activation of inflammatory caspases and processing of prolL-1 $\beta$. Mol. Cell 10: 417-426

21. Vancompernolle K, Van Herreweghe F, Pynaert G, Van de Craen M, De Vos K Totty N, Sterling A, Fiers W, Vandenabeele P and Grooten J (1998) Atractyloside-induced release of cathepsin $\mathrm{B}$, a protease with caspaseprocessing activity. FEBS Lett. 438: 150-158

22. Schotte P, Van Criekinge W, Van de Craen M, Van Loo G, Desmedt M, Grooten J, Cornelissen M, De Ridder L, Vandekerckhove J, Fiers W, Vandenabeele P and Beyaert R (1998) Cathepsin B-mediated activation of the proinflammatory caspase-11. Biochem. Biophys. Res. Commun. 251:379-387

23. Roberts LR, Adjei PN and Gores GJ (1999) Cathepsins as effector proteases in hepatocyte apoptosis. Cell. Biochem. Biophys. 30: 71-88

24. Foghsgaard L, Wissing D, Mauch D, Lademann U, Bastholm L, Boes M, Elling $F$, Leist $M$ and Jaattela M (2001) Cathepsin B acts as a dominant execution protease in tumor cell apoptosis induced by tumor necrosis factor. J. Cell Biol. 153: $999-1010$

25. Guicciardi ME, Miyoshi H, Bronk SF and Gores GJ (2001) Cathepsin B knockout mice are resistant to tumor necrosis factor- $\alpha$-mediated hepatocyte apoptosis and liver injury: implications for therapeutic applications. Am. J. Pathol. 159: 2045-2054
26. Nakayama $\mathrm{M}$, Ishidoh $\mathrm{K}$, Kayagaki $\mathrm{N}$, Kojima $\mathrm{Y}$, Yamaguchi N, Nakano $\mathrm{H}$, Kominami E, Okumura K and Yagita H (2002) Multiple pathways of TWEAKinduced cell death. J. Immunol. 168: 734-743

27. Taniguchi M, Nagaoka K, Kunikata T, Kayano T, Yamauchi H, Nakamura S, Ikeda M, Orita K and Kurimoto M (1997) Characterization of anti-human interleukin-18 (IL-18)/interferon- $\gamma$-inducing factor (IGIF) monoclonal antibodies and their application in the measurement of human IL-18 by ELISA. J. Immunol. Methods. 206: 107-113

28. Akita $K$, Ohtsuki T, Nukada $Y$, Tanimoto $T$, Namba M, Okura T, TakakuraYamamoto R, Torigoe K, Gu Y, Su MSS, Fujii M, Satoh-Itoh M, Yamamoto K, Kohno K, Ikeda M and Kurimoto M (1997) Involvement of caspase-1 and caspase-3 in the production and processing of mature human interleukin 18 in monocytic THP-1 cells. J. Biol. Chem. 272: 26595-26603

29. Yamin TT, Ayala JM and Miller DK (1996) Activation of the native $45-\mathrm{kDa}$ precursor form of interleukin-1-converting enzyme. J. Biol. Chem. 271: 1327313282

30. Poltorak A, He X, Smirnova I, Liu MY, Huffel CV, Du X, Birdwell D, Alejos E, Silva M, Galanos C, Freudenberg M, Ricciardi-Castagnoli P, Layton B and Beutler B (1998) Defective LPS signaling in C3H/HeJ and C57BL/10ScCr mice: mutations in Tlr4 gene. Science 282: 2085-2088

31. Watanabe N, Kawaguchi M and Kobayashi $Y$ (1998) Activation of interleukin$1 \beta$-converting enzyme by nigericin is independent of apoptosis. Cytokine 10 : $645-653$

32. Zhuang J, Dinsdale D and Cohen GM (1998) Apoptosis, in human monocytic THP1 cells, results in the release of cytochrome $\mathrm{c}$ from mitochondria prior to their ultracondensation, formation of outer membrane discontinuities and reduction in inner membrane potential. Cell Death Differ. 5: 953-962

33. Livingston DJ (1997) In vitro and in vivo studies of ICE inhibitors. J. Cell Biochem. 64: 19-26

34. Rabuffetti M, Sciorati C, Tarozzo G, Clementi E, Manfredi AA and Beltramo M (2000) Inhibition of caspase-1-like activity by Ac-Tyr-Val-Ala-Asp-chloromethyl ketone induces long-lasting neuroprotection in cerebral ischemia through apoptosis reduction and decrease of proinflammatory cytokines. J. Neurosci. 20: 4398-4404

35. Schotte P, Declercq W, Van Huffel S, Vandenabeele P and Beyaert R (1999) Non-specific effects of methyl ketone peptide inhibitors of caspases. FEBS Lett. 442: 117-121

36. Buttle DJ, Murata M, Knight CG and Barrett AJ (1992) CA074 methyl ester: a proinhibitor for intracellular cathepsin B. Arch. Biochem. Biophys. 299: 377380

37. Zhu DM and Uckun FM (2000) Cathepsin inhibition induces apoptotic death in human leukemia and lymphoma cells. Leuk. Lymphoma. 39: 343-354

38. Hentze H, Schwoebel F, Lund S, Kehl M, Ertel W, Wendel A, Jaattela M and Leist M (2001) In vivo and in vitro evidence for extracellular caspase activity released from apoptotic cells. Biochem. Biophys. Res. Commun. 283: 11111117

39. Wang KK (2000) Calpain and caspase: can you tell the difference? Trends Neurosci. 23: 20-26

40. Coolican SA, Haiech J and Hathaway DR (1986) The role of subunit autolysis in activation of smooth muscle $\mathrm{Ca}^{2+}$-dependent proteases. J. Biol. Chem. 261: 4170-4176

41. McCelland $P$, Lash JA and Hathaway $D R$ (1989) Identification of major autolytic cleavage sites in the regulatory subunit of vascular calpain II. A comparison of partial amino-terminal sequences to deduced sequence from complementary DNA. J. Biol. Chem. 264: 17428-17431

42. Wang $K K$, Nath $R$, Posner $A$, Raser $K J$, Buroker-Kilgore $M$, Hajimohammadreza I, Probert Jr. AW, Marcoux FW, Ye Q, Takano E, Hatanaka M, Maki M, Caner H, Collins JL, Fergus A, Lee KS, Lunney EA, Hays SJ and Yuen $P$ (1996) An alpha-mercaptoacrylic acid derivative is a selective nonpeptide cell-permeable calpain inhibitor and is neuroprotective. Proc. Natl. Acad. Sci. USA 93: 6687-6692

43. Stoka V, Turk B, Schendel SL, Kim TH, Cirman T, Snipas SJ, Ellerby LM, Bredesen D, Freeze H, Abrahamson M, Bromme D, Krajewski S, Reed JC, Yin $\mathrm{XM}$, Turk V and Salvesen GS (2001) Lysosomal protease pathways to apoptosis: cleavage of Bid, not pro-caspases, is the most likely route. J. Biol. Chem. 276: 3149-3157

44. Mehta VB, Hart J and Wewers MD (2000) ATP-stimulated release of IL-1 $\beta$ and IL-18 requires priming by LPS and is independent of caspase-1 cleavage. J. Biol. Chem. 276: 3820-3826 
45. Le Feuvre RA, Brough D, Iwakura Y, Takeda K and Rothwell NJ (2002) Priming of macrophages with lipopolysaccharide potentiates P2X7-mediated cell death via a caspase-1-dependent mechanism, independently of cytokine production. J. Biol. Chem. 277: 3210-3218

46. Furlong IJ, Ascaso R, Lopez Rivas A and Collins MK (1997) Intracellular acidification induces apoptosis by stimulating ICE-like protease activity. J. Cell. Sci. 110: 653-661

47. Li P, Allen H, Banerjee S, Franklin S, Herzog L, Johnston C, McDowell J, Paskind M, Rodman L, Salfeld J, Towne E, Tracey D, Wardwell S, Wei F-Y, Wong W, Kamen R and Seshadri T (1995) Mice deficent in IL-1 $\beta$-converting enzyme are defective in production of mature $\mathrm{IL}-1 \beta$ and resistant to endotoxic shock. Cell 80: 401-411

48. Nett-Fiordalisi M, Tomaselli K, Russell JH and Chaplin DD (1995) Macrophage apoptosis in the absence of active interleukin- $1 \beta$-converting enzyme. J. Leukoc. Biol. 58: 717-724

49. McGrath ME (1999) The lysosomal cysteine proteases. Annu. Rev. Biophys. Biomol. Struct. 28: 181-204

50. Turk V, Turk B and Turk D (2001) Lysosomal cysteine proteases: facts and opportunities. EMBO J. 20: 4629-4633

51. Reinheckel T, Deussing J, Roth W and Peters C (2001) Towards specific functions of lysosomal cysteine peptidases: phenotypes of mice deficient for cathepsin B or cathepsin L. Biol. Chem. 382: 735-741
52. Leist M and Jaattela M (2001) Triggering apoptosis by cathepsins. Cell Death Differ. 8: 324-326

53. Johnson DE (2000) Noncaspase proteases in apoptosis. Leukemia 14: 16951703

54. Foghsgaard L, Lademann U, Wissing D, Poulsen B and Jaattela M (2002) Cathepsin $B$ mediates tumor necrosis factor-induced arachidonic acid release in tumor cells. J. Biol. Chem. 277: 39499-39506

55. Morland B and Pedersen A (1979) Cathepsin B activity in stimulated mouse peritoneal macrophages. Lab. Invest. 41: 379-384

56. Li Q, Falkler WA and Bever CT (1997) Endotoxin induces increased intracellular cathepsin B activity in THP-1 cells. Immunopharmacol. Immunotoxicol. 19: 215-237

57. Beutler B (2000) TIr4: central component of the sole mammalian LPS sensor. Curr. Opin. Immunol. 12: 20-26

58. Leist M, Single B, Castoldi AF, Kuhnle S and Nicotera P (1997) Intracellular adenosine triphosphate (ATP) concentration: a switch in the decision between apoptosis and necrosis. J. Exp. Med. 185: 1481-1486

59. Bergmeyer HU (1983) Methods of Enzymatic Analysis, Vol 3. Weinheim: Verlag Chemie. 605pp.

60. Thornberry NA (1994) Interleukin-1 $\beta$ converting enzyme. Meth. Enzymol. 244: $615-631$ 